Research Report No. 45/2013

\title{
The Politics of Relevance: Law, Translation and Alternative Knowledges
}

Peer Zumbansen

Osgoode Hall Law School of York University, PZumbansen@osgoode.yorku.ca

Follow this and additional works at: http://digitalcommons.osgoode.yorku.ca/clpe

\section{Recommended Citation}

Zumbansen, Peer, "The Politics of Relevance: Law, Translation and Alternative Knowledges" (2013). Comparative Research in Law \& Political Economy. Research Paper No. 45/2013.

http://digitalcommons.osgoode.yorku.ca/clpe/287 


\section{OSGOODE}

OSGOODE HALL LAW SCHOOL

YOR K UNIVERSITY

\section{OSGOODE HALL LAW SCHOOL}

Comparative Research in Law \& Political Economy

RESEARCH PAPER SERIES

Research Paper No. 45/2013

The Politics of Relevance: Law, Translation and Alternative Knowledges

Peer Zumbansen

Editors:

Peer Zumbansen (Osgoode Hall Law School, Toronto, Director Comparative Research in Law and Political Economy)

John W. Cioffi (University of California at Riverside)

Comparative Research in Law \& Political Economy 


\title{
The Politics of Relevance: Law, Translation and Alternative Knowledges
}

\author{
PeER Zumbansen*
}

\begin{abstract}
The gap between law's pronouncement of rules and their impact or failure in concrete social environments has long prompted efforts to make lawyers more responsive to the "realities on the ground". While this turn to sociological jurisprudence seemed a logical consequence of the Legal Realists' attack on formalism and positivism, it exposed legal theory to a never-ending series of questions concerning the limits of law in becoming an empirically informed social science. Even trailblazing Legal Realists themselves questioned the extent to which empirical knowledge might erode the core of law's claim to authority. Where are we today, after numerous transgressions à la "law \& economics", "law \& society", "law \& psychology" etc? But, how should this question be answered in light of the globalization of social relations, that has brought about the rise of numerous, border-crossing regulatory regimes, comprised of national/international, hard/soft, official/in-official 'legal' norms? Do these developments merely suggest a reprise of last century's sociological turn?
\end{abstract}

In this article, I want to suggest that there is a significant difference between the current interest of law in sociology (anthropology, geography) and the earlier instance of legal sociology. Whereas historically earlier stances responded, in no small degree, to legal positivism and, eventually, to both technological and societal change, the current social scientific engagement by lawyers appears driven by a differently articulated concern, even anxiety, about the viability of legal analytical, conceptual and semantic tools in a changed, transnational context. With the shift of law's bearings from the nation-state to globalization's strange land, law's need to learn anew and differently can be felt throughout: in textbooks, classrooms, professional ethics and legal practice. In light of the again growing importance of interdisciplinarity, legal pluralism and globalization, law's new frontier might lie in its reconstitution as transnational sociological jurisprudence. At the center of such an enterprise lies an engagement with the ways in which legal "fields" are conceptualized and put into practice as determinative translations between competing sets of knowledge. The here made contention is that underneath the shifts between different disciplinary approaches to law in the context of legal sociology, comparative law, post-colonial studies or different iterations of "law and..." (culture, history, anthropology, geography etc) are longstanding questions regarding law as doctrine, theory, practice, culture. These are re-emerging with particular thrust in the transnational regulatory realm, that is to markedly characterized by the absence of institutional infrastructures known from the Western rule of law and welfare state traditions.

\footnotetext{
- This article is based on a presentation at the IJGLS Conference on "Regulatory Translations", Istanbul, 16-18 May 2013. The author is grateful to Umut Turem, Andrea Ballestero and Fred Aman for organizing an inspiring interdisciplinary conference and to Jothie Rajah, Anna-Katharina Kaufmann and Philip Liste for very helpful comments and feedback. An earlier, shorter version is included in the edited collection "Law in Transition: Rights, Development and Transitional Justice (R.Buchanan \& P.Zumbansen, eds., Hart Publishing, 2013) under the title "Sociological Jurisprudence 2.0".

${ }^{*}$ LL.B./JD equivalent, Frankfurt; Licence en droit, Paris; LL.M., Harvard; Ph.D., Habilitation, Frankfurt. Professor of Law and Canada Research Chair, Osgoode Hall Law School, Toronto. Senior Research Scholar, Michigan Law School, and Visiting Professor, Yale Law School. Email: Pzumbansen@osgoode.yorku.ca
} 


\section{INTRODUCTION}

Two recent decisions of the United States Supreme Court, handed down in June 2013, have been attracting considerable attention - most presumably because of their "bigger picture" significance in the context of public political debate in the area of equal protection. The Court's pronouncement in United States $v$ Windsor ${ }^{1}$ was concerned at its center with the contested constitutionality of the federal DEFENCE OF MARRIAGE ACT [DOMA] of $1996^{2}$, according to which marriage was defined as a "bond between one man and one woman". ${ }^{3}$ The Court struck down sec. 3 of the Act, holding it to be a violation of the equal protection clause under the 5th amendment. Decided the same day, in Hollingsworth v Perry, the Court ruled that a petitioner group that defended the constitutionality of a California constitutional amendment rendering same-sex marriages illegal had no standing, where the government had opted not to stand trial to defend this amendment (the so-called Proposition 8). ${ }^{4}$ These two decisions stand squarely within a much belabored context of legal, political and cultural battles over equal protection and privacy rights. ${ }^{5}$ Yet, if we wanted to clearly demarcate different legal fields touched upon by these cases, we would very soon find ourselves enumerating one regulatory regime after another. As the author of the opinion in Windsor, Justice Kennedy, noted, the enactment of DOMA put into place a statute that would directly and indirectly have an impact on "over 1,000 federal statutes", with the consequence that the decision, on its face concerned with a particular legal definition operated in fact in many different legal arenas simultaneously, ranging from constitutional to social insurance law, from housing to trusts and estates, from tax law to family and adoption law as well as landlord and tenant law. At the same time, all of these fields would be mobilized in a context, which gives rise to intriguing questions of procedural law and federalism.

It would seem, then, that both decisions are 'local' in that they arise out of a particularly U.S. American regulatory and adjudicatory context and can be read, understood and appreciated against this very background. And yet, taking just one step 'aside', we can see how the issues at work in Windsor as well as in Perry are by no means exclusively proprietary to the American constitutional discourse. Instead, we can easily discern a number of comparative connections to similarly situated legal disputes in foreign jurisdictions where the question of same sex marriage has long become a hot topic of legal and public deliberation. As becomes clear already in Windsor from the fact that the plaintiff, Edith Schlain Windsor, and her late partner, Thea Clara Spyer, had entered a relationship in the 1960s and then been married under newly enacted law in Ontario, Canada in 2007, they had "shopped" for a legal regime that would accommodate their aspiration for formal legal recognition of their relationship before such norms would become

\footnotetext{
${ }^{1}$ United States v. Windsor, 570 U.S.____ (2013), arg. 27 March, dec. 26 June 2013.

${ }^{2}$ Pub.L. 104-199, $110 \underline{\text { Stat. 2419 }}$, enacted September 21, 1996, 1 U.S.C. $\S 7$ and 28 U.S.C. $\S 1738 C$

3 Defence of Marriage Act, Sec. 3

${ }^{4}$ Hollingsworth et. v. Perry et al., 570 U.S.___ (2013), arg. 26 March 2013, dec. 26 June 2013.

${ }^{5}$ See Romer v Evans, 517 U.S. 620 (1996); Lawrence v. Texas, 539 U.S. 558 (2003).
} 
available in the U.S. ${ }^{6}$ The case arose out of the tax levied onto Ms Windsor to whom Ms Spyer had bequeathed her entire estate, a tax that the IRS had justified with reference to DOMA, despite the fact that the state of New York had formally recognized the legality of the marriage concluded under Canadian law, when Windsor and Spyer returned to their residency in New York - two years before Ms Spyer deceased in 2009. A growing number of other countries, then, including Canada of course, has seen comparable developments in the granting, expansion or limitation of equal protection guarantees in the area of same sex relationships. ${ }^{7}$

This observation would place the otherwise "American" set of cases that we just referred to in a context of so-called comparative constitutional law, an area of legal research with a considerably young and yet already significant pedigree ${ }^{8}$, both as regards its impressive theoretical progress ${ }^{9}$ as well as its practical-political importance in the context of transnational judicial dialogue. ${ }^{10}$ Seen through the lens of comparative law, we are able to study a 'local' jurisprudential event such as the U.S. Supreme Courts' decisions of June 2013 as illustrations of a change in legal (political, cultural) perception under way in other countries as well. Indeed, many areas often considered exclusively in a local, domestic context, reveal their transnational dimension ${ }^{11}$ once we begin to trace more carefully the trajectories and impacts of 'migrating' norms, principles and standards. ${ }^{12}$ But, once we direct our attention to such changes in the law across a growing range of jurisdictions, we can begin to discern the particular nature in which such changes grow out of debates and legal, jurisprudential developments that are local and transnational at the same time. $^{13}$

\footnotetext{
${ }^{6}$ For more background on the concept of“shopping“ for law, see ERIN A. O'HARA AND LARRY E. RIBSTEIN, THE LAW MARKET (2009); Horst Eidenmüller, The Transnational Law Market, Regulatory Competition, and Transnational Corporations, ms. 2010, available at: http://ssrn.com/abstract=1681982 (last visited 30 August 2013).

${ }^{7}$ See, e.g., Kelly Kollman, Same-Sex Unions: The Globalization of an Idea, 51 INT’L STUD. QUART. 329 (2007) ; more recent data may be retrieved at: http://en.wikipedia.org/wiki/Same-sex_union_legislation

${ }^{8}$ Mauro Cappelletti/William CohEn, Comparative CONSTITUTIONAL LAW (1979); DuRGa Das Basu, COMPARATIVE CONSTITUTIONAL LAW (1984); VICKI C. JACKSON/MARK TUSHNET, COMPARATIVE CONSTITUTIONAL LAW 2ND. ED. (2006); NORMAN DORSEN/MiCHEL ROSENFELD/ANDRÁS SAJÓ/SUSANNE BAER, COMPARATIVE CONSTITUTIONALISM. CASES AND MATERIALS. 2ND ED. (2010), $36 \mathrm{ff}$

${ }^{9}$ Gérard V. La Forest, The Expanding Role of the Supreme Court of Canada in International Law Issues, 34 CANADIAN YEARBOOK OF INTERNATIONAL LAW 89 (1996); Louise Arbour/Fannie Lafontaine, Beyond SelfCongratulation: The Charter at 25 in an International Perspective, 45 OsGOODE HALL LAW JOURNAL 239 (2007); Sujit Choudhry, Globalization in Search of Justification: Toward a Theory of Comparative Constitutional Interpretation, INDIANA LAW JOURNAL 819 (1999), 941: “A court's choice of interpretive methodology will affect more than the outcome the particular case before it. It will also likely affect the broader constitutional culture of the interpreting court's jurisdiction.”

${ }^{10}$ Anne-Marie Slaughter, Judicial Globalization, 40 VIRGINIA JOURNAL OF INTERNATIONAL LAW 1103 (2000); Alexandra Kemmerer, Constitutional Law as Work of Art - Experts' Eyes: Judges of the World Examine the Constitution of Europe, 4 GERMAN L.J. 859 (2003).

${ }^{11}$ For more background, see Peer Zumbansen, Comparative, Global and Transnational Constitutionalism: The Emergence of a Transnational Constitutional Pluralist Order, 1 GLOBAL CONSTITUTIONALISM 16 (2012).

${ }^{12}$ Sujit Choudhry (ed.^eds.), The MigRATION OF CONSTITUTIONAL IDEAS (2006).

${ }^{13}$ This is the perspective taken by legal scholars and political scientists interested in the "spatial turn": for an insightful illustration and engagement, see Philip Liste, Lost Without a Translation? Cross-Referencing and a New Global Community of Courts, 21 IND. J. GLOB. LEG. STUD. (2014) [this issue]
} 
A "field" area such as comparative constitutional law or, as authors have convincingly been arguing, constitutionalism ${ }^{14}$, appears inherently unstable, both as regards its substantive content and its analytical contours. Indeed, as we become witnesses of ever more proliferating ways and forms of legal "transplants" in hard and soft, formal and informal shapes ${ }^{15}$, it appears as if what we can here perceive resembles in many ways the types of a transnationalization of law, which in particular commercial lawyers have long been highlighting as a promising laboratory to study the modern evolution of legal norm generation and dissemination. ${ }^{16}$ Likewise, as in our present example, in areas where we are concerned with sensitive societal questions of regulatory intervention, we will increasingly find dynamics of 'borrowing', 'mimicking', 'impregnation' and other forms of travelling norms and principles, promulgated by courts' in one country citing courts in other countries, by judges (and other officials) engaging in transnational dialogue ${ }^{17}$, or by a form of legal transplant that in itself merits very close attention. Complementing, sometimes trailing, but most frequently driving states' action, private transnational actors can be seen to significantly engage in processes of norm development and generation. In the here used example of the Supreme Court's same sex decisions, the importance of the just announced business policy on the part of Wal-Mart to extend its employee-directed health care benefits package to same sex partners is of particular interest. ${ }^{18}$ Considering the fact that the country's single largest employer with about 1.3 million employees in the U.S. (with a total of 2.2 million worldwide ${ }^{19}$ ) adopts such a policy without a legal obligation to do so, points to the particular relations between "public" and "private" norm making processes. The sheer factual size of this regulatory program prompts a closer scrutiny as to the "legal" nature of such a set of self-imposed obligations. Closely related to such questions of how to demarcate the legal nature of the processes before the Supreme Court and the purported non-law character of Wal-Mart's newly enacted policy are concerns with the character of the institutions involved in norm-generation as such. To some degree, such questions are still hypothetical, as a corporation such as Wal-Mart is not considered an entity granted with the authority to issue binding legal norms. And yet, the tight integration of "private" actors in various, wide-spread norm producing and implementing contexts in the area

\footnotetext{
${ }^{14}$ See DORSEN ET AL., supra, note

${ }^{15}$ For an insightful illustration, see Iza Hussein, How, and Why, Law Travels: Translations, Circulations, Transformations, 21 IND. J. GLOB. LEG. STUD.___(2014) [this issue]

${ }^{16}$ See, e.g., JH Dalhuisen, Legal Orders and their Manifestation: The Operation of the International Commercial and Financial Legal Order and its Lex Mercatoria, 24 BERKELEY JOURNAL OF INTERNATIONAL LAW 129 (2006); Roy Goode, Usage and Its Reception in Transnational Commercial Law, 46 INTERNATIONAL AND COMPARATIVE LAW QUARTERLY 1 (1997); Ross Cranston, Theorizing Transnational Commercial Law, 42 TEXAS INTERNATIONAL LaW Journal 597 (2007); Gralf-Peter Calliess/Moritz Renner, The Public and the Private Dimensions of Transnational Commercial Law, 10 GERMAN LAW JOURNAL 1341 (2009).

${ }^{17}$ See, e.g., the program on "Transnational Judicial Dialogue", carried out under the auspices of the American Society of International Law (http://www.asil.org/transnational-judicial-dialogue.cfm - last visited 28 August 2013): "Through formal and informal networks, judges from jurisdictions and courts around the world are engaged in a transnational dialogue on strengthening international judicial cooperation, improving the coherence of international and national law, and advancing the rule of law and respect for human dignity on a global scale.” Id.

${ }^{18}$ Anne D’Innocenzio, Wal-Mart extends health care benefits to workers' domestic partners, including same-sex, 28 August 2013, HuFFINGTON POST, available at: http://www.huffingtonpost.ca/2013/08/27/wal-mart-extends-healthc_n_3825793.html?utm_hp_ref=canada-style

${ }^{19}$ http://corporate.walmart.com/our-story/locations (last visited 28 August 2013)
} 
of environmental ${ }^{20}$, commercial $^{21}$ or financial regulation ${ }^{22}$ suggests that the lines between private actors (without law making authority) and public ones (with such authority) are not as neatly drawn as some might think. Depending on whether we would attribute a legal character to WalMart the next question would be indeed to rethink the status of such a norm-producing actor or entity, its public or private character. As Legal Realists have long ago argued ${ }^{23}$, such a reflection is especially important where real social consequences follow from such "abstract” legal categorization. $^{24}$

In this article I am interested in this particular constellation of what I want to call "political legal theory" 25 and the today fast proliferating field of 'transnational regulatory governance' ${ }^{\text {, }}$, both of which I hope to eventually integrate and conceptualize as Transnational Sociological Jurisprudence. In the following, I argue for the need to engage in particular processes of "translation" in order to more adequately grasp the dynamics as well as consequences of allegedly clearly defined legal-regulatory areas with their corresponding epistemologies (captured through their depiction as legal “fields”). In previous work, I have been interested in the identification of "translation categories" - using the examples of Actors, Norms, and Processes - to capture the theoretical and conceptual challenges arising in a context where are called upon to offer legal analysis and doctrinal assessments in a framework very different from

\footnotetext{
${ }^{20}$ See Yasmine Chahed, Translations in Regulatory Space: The Arenas of Regulatory Innovation in Accounting Standard-Setting, 21 IND. J. GLOB. LEG. STUD.___(2014) [this issue]; see also Michael Power, Constructing the Responsible Organization: Accounting and Environmental Representation, in: ENVIRONMENTAL LAW AND

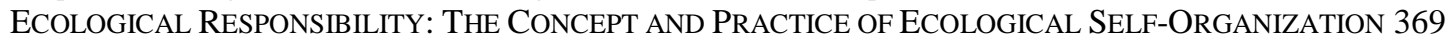
(Teubner/Farmer/Murphy, eds., 1994); Tim Bartley, Institutional Emergence in an Era of Globalization: The Rise of Transnational Private Regulation of Labor and Environmental Conditions, 113 AMERICAN JOURNAL OF SOCIOLOGY 297 (2007).

${ }^{21}$ Jens Wüstemann/Sonja Kierzek, Transnational legalization of accounting: the case of international financial reporting standards, in: LAW AND LEGALIZATION IN TRANSNATIONAL RELATIONS 33 (Brütsch/Lehmkuhl, eds., 2007); Walter Mattli, Public and Private Governance in Setting International Accounting Standards, in:

GOVERNANCE IN A GLOBAL ECONOMY 199 (Kahler/Lake, eds., 2003).

${ }^{22}$ See, e.g., Michael S. Barr/Geoffrey P. Miller, Global Administrative Law: The View from Basel, 17 EUROPEAN Journal OF INTERNATIONAL LAW 15 (2006); Caroline Bradley, Private International Law-Making for the Financial Markets, 29 FORDHAM INTERNATIONAL LAW JOURNAL 127 (2005).

${ }^{23}$ Robert L. Hale, Bargaining, Duress and Economic Liberty, 43 COLUMBIA LAW ReVIEW 603 (1943); Roscoe Pound, The New Feudalism, 16 AmERICAN BAR AssoCiATION JOURNAL 553 (1932).

${ }^{24}$ John Dewey, The Historic Background of Corporate Legal Personality, 35 Yale Law Journal 655 (1926); for a review of this strain of legal realist analysis for contract and corporate law, see Peer Zumbansen, The Law of Society: Governance Through Contract, 14 IndiANA JouRnAL OF GLOBAL LEGAL STUDIES 191 (2007), and Peer Zumbansen/Simon Archer, The BCE Decision: Reflections on the Firm as a Contractual Organization, CLPE COMPARATIVE RESEARCH IN LAW \& POLITICAL ECONOMY RESEARCH PAPER available at: http://ssrn.com/abstract=1160094 (2008).

${ }^{25}$ Here, I am much inspired by Rudolf Wiethölter's longstanding analysis of the correlation between political, sociological and economic analysis of law. See, e.g., Rudolf Wiethölter, Social Science Models in Economic Law, in: CONTRACT AND ORGANiSATION. LEGAL ANALYSIS IN THE LIGHT OF ECONOMIC AND SOCIAL THEORY 52 (Daintith/Teubner, eds., 1986), as well as Rudolf Wiethölter, Materialization and Proceduralization in Modern Law, in: Dilemmas of LAW IN THE Welfare STATE 221 (Teubner, ed., 1986).

${ }^{26}$ A landmark contribution to this debate continues to be Claire Cutler's study of the institutional and political dimensions of lex mercatoria: A. Claire Cutler, Private POWER AND GLOBAL Authority: TrANSNATIONAL MERCHANT LAW IN THE GLOBAL ECONOMY (2003).
} 
that of a (Western) nation state, marked by evolving conceptions of the state, the rule of law, notions of the separation of powers and a system of normative hierarchy, with some form of constitutional text or order at the pinacle of the pyramid. ${ }^{27}$ In the present context, translation is seen to occur in two ways: first in the form of the Legal Realist confrontation of legal norms with their invisibilized social realities, secondly through a close study of the ways in which the content and boundaries of legal fields are being drawn and justified. The key here is a contextualization of lawyers' demarcation discourses as concerns the function and boundaries of particular legal areas ("fields") in a never fully disclosed or disclosable realm of epistemological conceptualization. What - in the domestic context - would, for example, justify a strict separation between labor law on the one hand and corporate law, on the other? We should know and did already know for a long time ${ }^{28}$, that the justification of distinguishing between these two legal fields, despite its "functional" persuasiveness ${ }^{29}$ is at its core political. As will be shown later in this article, similar justificatory moves occur in both emerging and maturing transnational legal fields: the here chosen examples of law \& development and transitional justice do poignantly mirror the same thrust of arguments mobilized to distinguish their respective regulatory function. It is by approximating these fields that we can see more clearly how the construction of a legal field results in the creation of a tightly structured, hermetically closed political universe.

But, as I want to show in the following, this attention to politics does not go far enough. What today is most frequently being associated with the need to expand law's interdisciplinary capacity $^{30}$, is in fact only the surface of a more comprehensive crisis of law's epistemological foundations. On the one hand, from a legal-sociological perspective, we find an increasingly fuzzy relationship between allegedly "public" and "private” actors involved in the formulation and implementation as well as enforcement of norms. But, while this proliferation of private regulatory actors is as such not a novelty given its historical precursors ${ }^{31}$, its particular appearance in the context of the continuing crisis and transformation of the New Deal's and the post-war Welfare State's regulatory aspirations ${ }^{32}$ requires a comprehensive analyis that would

\footnotetext{
${ }^{27}$ Compare Peer Zumbansen, Lochner Disembedded: The Anxieties of Law in a Global Context, 20 INDIANA JOURNAL OF GLOBAL LEGAL STUDIES 29 (2013), 54-60.

${ }^{28}$ Adolf A. Berle, The 20th Century Capitalist Revolution (1954); William W. Bratton, Welfare, Dialectic, and Mediation in Corporate Law, 2 BERKELEy Business LAW JouRnAL 59 (2005); Fenner L. Stewart, Berle's Conception of Shareholder Primacy: A Forgotten Perspective for Reconsideration During The Rise of Finance, 34 SEATTLE U. L. REV. 1457 (2011)

${ }^{29}$ John Dewey, The Historic Background of Corporate Legal Personality, 35 YALE LAW JOURNAL 655 (1926); William W. Bratton, The 'Nexus of Contracts' Corporation: A Critical Appraisal, 74 CORNELL LAW REVIEW 407 (1989); Simon Deakin, 'Enterprise-risk': the juridical nature of the firm revisited, 32 INDUSTRIAL LAW JOURNAL 97 (2003).

${ }^{30}$ See, e.g., NYU’s 2012-2013 Hauser Colloquium program, focusing on an interdisciplinary analysis to place legal theory in the interdisciplinary context of global governance: http://www.law.nyu.edu/academics/colloquia/hauserglobal (last visited 28 August 2013).

${ }^{31}$ See, e.g., Louis Jaffe, Law Making by Private Groups, 51 HARVARD LAW REVIEW 201 (1937); Karl Llewellyn, What Price Contract? - An Essay in Perspective, 40 YALE LAW JOURNAL 704 (1930).

${ }^{32}$ Orly Lobel, The Renew Deal: The Fall of Regulation and the Rise of Governance in Contemporary Legal Thought, 89 MinNESOTA LAW REVIEW 342 (2004); for an intriguing analysis of the current privatization and
} 
effectively revisit and reinvigorate the Legal Realists' pondering on the hidden politics of depoliticizing markets ${ }^{33}$, contracts ${ }^{34}$ and families. ${ }^{35}$ The first strand of analysis in this article is thus an attempt to connect the contemporary politics over post-Welfare State regulatory governance with earlier contentions as to the ideological basis of market-state demarcations. On the other hand, such analysis must prove adequate in the face of a fundamentally transformed institutional environment as it presents itself in the form of today's "disembeddedness" of the nation state's regulatory and adjudicatory apparatus. ${ }^{36}$ The disaggregation of a wide range of state regulatory functions and processes ${ }^{37}$ presents, thus, a formidable challenge and laboratory for the study of the doctrinal, conceptual as well as ethical and political dimensions of norm creation and implementation. ${ }^{38}$

At the heart of this article is thus the correlation between a "political" critique of legal theory and an analysis of the relationship between law and governance in a transnational context. It is through the mobilization of the idea of "translation" that I hope to be able to show how contemporary calls for a more interdisciplinary study of law can barely scratch the surface of what is in fact a far deeper-reaching political crisis of law, a crisis that is one of law's epistomological basis. Against this background, the agenda is a relatively straight forward one. Once the importance of the Realists' political critique of legal formalism is reintroduced, the task consists in reflecting on the challenges arising in the attempt to apply their lessons to contemporary arenas of transnational governance. The concept of translation will be unfolded in two ways: the first is to revisit the ubiquitous reference to "public" and "private" in a by now well-established "law \& society" mode, which builds on legal realism and places law as a social theory enterprise in an ever-further differentiated social science context. ${ }^{39}$ But, we need to look at the challenges of a thus operating law \& society approach that risks simultaneously fetichizing

contractualization politics in local welfare deregulation, see Alfred E. Aman Jr., Privatization in Indiana, 20 IND J GLOB LEG STUD __ (2013).

${ }^{33}$ Robert L. Hale, Coercion and Distribution in a Supposedly Non-Coercive State, 38 PolitiCAL SCIENCE QUARTERLY 470 (1923)

${ }^{34}$ Morris R. Cohen, The Basis of Contract, 46 HaRVARD LAW Review 553 (1932); Clare Dalton, An Essay in the Deconstruction of Contract Doctrine, 94 Yale LaW Journal 997 (1985); Danielle Kie Hart, Contract Formation and the Entrenchment of Power, 41 LOYOLA CHICAGO LAW JOURNAL 175 (2009)

${ }^{35}$ Frances E. Olsen, The Family and the Market: A Study of Ideology and Legal Reform, 96 HARVARD LAW REVIEW 1497 (1983)

${ }^{36}$ Zumbansen, Lochner Disembedded, supra, note

${ }^{37}$ Anne-Marie Slaughter, Disaggregated Sovereignty: Towards the Public Accountability of Global Government Networks, 39 GOVERNMENT AND OPPOSITION 159 (2004); Pierre-Hugues Verdier, Transnational Regulatory Networks and Their Limits, 34 YALE JOURNAL OF INTERNATIONAL LAW 113 (2009)

${ }^{38}$ Colin Scott, Regulatory Governance and the Challenge of Constitutionalism, EUI WORKING PAPERS. ROBERT SCHUMAN CENTRE FOR ADVANCED STUDIES, Private Regulation Series-02 http://ucd (2010); see also the contributions to Colin Scott/Fabrizio Cafaggi/Linda Senden (ed.^eds.), The Challenge of Transnational Private Regulation: Conceptual and Constitutional Debates. Symposium Issue of the JOURNAL OF LAW AND SOCIETY, Vol. 38, No. 1, pp. 1-188 (2011), and Peer Zumbansen, The Ins and Outs of Transnational Private Regulatory Governance: Legitimacy, Accountability, Effectiveness and a New Concept of 'Context', 13 GERMAN LAW JOURNAL 1269 (2012).

${ }^{39}$ For a very fruitful application in the context of globalization, see now EVE DARIAN-SMITH, LAWS AND SOCIETIES IN GLOBAL CONTEXTS (2013). 
and diffusing the "political” thrust that drove the Legal Realists' project. In light of this challenge, the present frontier of a renewed law \& society approach in the light of already made advances in sociology, philosophy and STS $^{40}$ lies, in my understanding, in how to more effectively engage legal doctrine and legal theory in a dialogue with those disciplines that place the questionable, fragmentary and precarious nature of knowledge at the center of their inquiry. This "turn to knowledge" as a task for legal theory turns, in a second step, practical when we study the establishment and demarcation of legal fields in contexts that are above all marked by the absence of the earlier available reference points for nation-state embedded legal governance. In other words, to the degree that fields such as law \& development and transitional justice are being constructed and distinguished from one another by using the old, traditional conceptualizations of (a-political) markets, (interventionist and, as such, market processes disrupting) states, (self-interested( individuals, (private) corporations and (contractualized) employees in the realm of the first field (L\&D) and the rule of law, reconciliation, prosecution and healing in that of the other (TJ), a Legal Realist inspired critique of the "hidden politics" might not prove sufficient to grasp what really lies at the center of these fields. Ultimately, I will argue that both $L \& D$ and TJ are mere facets of the way in which legal theory today engages with a complex regulatory as well as normative-ethical reality. Using the concept of translation in the described two ways will allow us to see more clearly how distinctions between public and private, political and non-political elements of this reality are closely linked to distinctions between legal and non-legal forms of social ordering. Underlying these distinctions is a firece struggle over different utopia, over competing and likely mutually exclusive models of society and human community ${ }^{41}$, a struggle about the violence of which the lawyers' distinction between "relevant" and "irrelevant" social facts in court proceedings gives little to no indication. ${ }^{42}$

A central contention of this article is that the future development of 'law and globalization' will significantly be shaped by the way that scholars in law and other social sciences are able to further integrate the respective investigations into foundations and methodology, that are under way in each discipline, as we speak. The prospect of updating and adapting a primarily nationstate focused legal discipline to its operation in a global context includes the initiations of concentrated thought exchanges about the different, recognizable approaches to make sense, above all, of the challenges posed by globalization for law and other social sciences. For a

\footnotetext{
${ }^{40}$ Michel Callon, Some Elements of a Sociology of Translation: Domestication of the Scallops and the Fishermen of St Brieuc Bay, in: Power, Action And BeliEf: A New Sociology of KNowledge 196 (Law, ed., 1966); Bruno Latour, From Realpolitik to Dingpolitik, or How to make things public, in: MAKING THINGS PUBLIC. ATMOSPHERES OF DEMOCRACY 14 (Latour/Weibel, eds., 2005).

${ }^{41}$ For a brillant depiction of this point, see Roger Cotterrell, Spectres of Transnationalism: Changing Terrains of Sociology of Law, 36 JOURNAL OF LAW AND SOCIETY 481 (2009), and for an insightful engagement with Cotterrell's approach (building on Georges Gurvitch), see Helge Dedek, When Law Became Cultivated: 'European Legal Culture' between Kultur and Civilization, in FORTHCOMING BOOK - REFERENCE TO FOLLOW

${ }^{42}$ It is this angle of analysis that is also proving crucial and helpful in the ongoing shifts of moral and epistemological justifications for changes in the law: a powerful example is Jothie Rajah's analysis of the emergence of a particular legal epistemology based on which the targeted killing of terrorists becomes a legal possibility. See Rajah, Sinister Translations: Law's Authority in a Post-9/11 World, 21 IND. J. GLOB. LEG. STUD. issue]. (2014) [this
} 
conversation across disciplinary boundaries to take flight, it is advisable to give a better picture of law and the current state of legal research (and, contemporary developments in legal education). The following list identifies a number of thematic clusters that capture the different aspects of contemporary debates around law and globalization. My contention is that, taken together, these clusters constitute elements of an emerging legal theory of global governance. Such a theory, to be sure, is no longer a legal theory in its own right, but a social theory of law. And it is in that light, that we are now experiencing a strange mixture of both déja-vu and innovation in the engagements between legal theory and social sciences. If we dared to apply a label to these developments, we could venture that of a transition from 'law \& society' to 'law \& globalization', with the term 'transition' marking less of a substitute and replacement than an evolution, a maturing and continuing differentiation. That said, however, it is clear that the challenges arising from the first phase of law \& society are likely to echo in the current iteration of law \& globalization. In other words, the pressing questions as to the methodology to unfold the relation between "law" and "society" cannot be considered obsolete. What remains the same, is the need to demarcate and motivate the contours of each and the boundaries between them. This brings us back to the rediscovery of legal sociology in the 1960s and 1970s, the rise of a scientifically driven criminology as one of the launching pads and benchmarks for what result in a fast proliferating field of victimology, critical criminal law theory, implementation and context studies etc. At the same time, "legal pluralism”, while echoing a lot of the early legal anthropologists’ and legal sociologists’ interests in indigenous legal orders or customary law ${ }^{43}$, became a very ambitious theoretical and practical endavor in the critical analysis of regulatory regimes in mature welfare states. ${ }^{44}$ Today, the resurgence of law \& society through the prism of law \& globalization reminds us of these demarcation efforts while pushing us to recontextualize such concerns in a newly expanded environment - jurisdictionally and geographically ${ }^{45}$, geopolitically ${ }^{46}$ and from an epistemological standpoint. ${ }^{47}$ What has changed in comparasion between the 1960s/1970s constellation and the present time, is that the target areas of much of the just mentioned legal sociological, anthropological and critical work have become de-centred, as it were, shifting from a largely state-centred analytical universe to one of hybrid regulatory arenas, described, variably as international 'regimes ${ }^{48}$, transnational 'spaces' ${ }^{49}$, fragmented

\footnotetext{
${ }^{43}$ EUgen EHRLICH, Fundamental PRINCIPLES OF THE SOCIOLOGY OF LAW (orig. published in German as GRUNDLEGUNG DER SozIOLOGIE DES RECHTS, 1913) (1962); Emile Durkheim, The Division of Labor in Society [1893; transl. by W.D. Halls], trans. by Halls (1984); ADDA B. BOZEMAN, THE FUTURE OF LAW IN A MULTiCUltURAL WORLD (1971).

${ }^{44}$ Sally Falk Moore, Law and Social Change: the semi-autonomous field as an appropriate subject of study, 7 LAW \& SOCIETY REVIEW 719 (1973); Gunther Teubner, Substantive and Reflexive Elements in Modern Law, 17 LAw \& SOCIETY REVIEW 239 (1983).

${ }^{45}$ Richard Ford, Law's Territory (A History of Jurisdiction), 97 MiCHIGAN LAW REVIEW 843 (1999); Gunther Handl/Joachim Zekoll/Peer Zumbansen (ed.^eds.), BEYOND TERRITORIALITY: TRANSNATIONAL LEGAL AUTHORITY IN AN AGE OF GLOBALIZATION (2012).

${ }^{46}$ David HeLd, Democracy AND THE Global Order (1995); Mathias Albert/Rainer Schmalz-Bruns, Antinomien der Global Governance: Mehr Weltstaatlichkeit, weniger Demokratie?, in: SOZIALE WeLT (SONDERBAND 18): DEMOKRATIE IN DER WELTGESELLSCHAFT 57 (Brunkhorst, ed., 2009).

${ }^{47}$ Boaventura de Sousa Santos, Beyond Abyssal Thinking. From global lines to ecologies of knowledge, EuROzINE http://www.eurozine.com/articles/2007 (2007); DIPESH CHAKRABARTY, PROVINCIALIZING EUROPE. POSTCOLONIAL THOUGHT AND HistoriCAl DifFERENCE, 2ND ED. [orig. 2000] (2007); JEAN COMAROFF/JOHN L. COMAROFF, THEORY FROM THE SOUTH: OR, HOW EURO-AMERICA IS EVOLVING TOWARD AFRICA (THE RADICAL IMAGINATION) (2011), especially ch 1, where C\&C lay out the different theoretical strands that inform their thesis.

${ }^{48}$ Stephen D. Krasner (ed.^eds.), International Regimes (2001).

${ }^{49}$ Saskia SAssen, Territory - Authority - Rights. From Medieval to Global Assemblages (2006).
} 
legal orders ${ }^{50}$ or 'collisions'. ${ }^{51}$ This shift results in what might be called a 'disembedding' of nation-state or jurisdiction-oriented analytical and conceptual approaches. Explanatory frameworks employed to structure and analyze core institutional features of state-based legal regimes such as the 'rule of law', the 'separation of powers' principle or the ideas of a constitutional order or, simply, normative hierarchy threaten to miss the unique architectural structure of emerging global governance regimes. It is this disembedding of state-based conceptual toolkits that prompts not so much a full-blown crafting of a 'new' language ${ }^{52}$, but a constant exersice in adaptation, building on reflexive exercises in (discourse-regime-system) translation $^{53}$ as well as the continuing engagements with the tension between 'government' and 'governance' discourses from in different social science disciplines . ${ }^{54}$

Such developments can be seen as forming the backdrop for the next stages of 'globalization studies', which will in all likelihood lead to an ever higher degree of interdisciplinary pollination. For the purposes of the present project it is necessary to keep this rich background in mind, while continuing the efforts to draw more concrete lessons from this engagement for one's own discipline. This interest in 'one's own' may be justified in light of the consideration that disciplinary frameworks evolve both internally and externally and as such have an inherent quality of instability that needs to be kept in mind when employing its tools and concepts however critically such employment may be occurring. What evolutionary theorists have referred as the tension between 'routine' and 'innovation' ${ }^{55}$, legal scholars have depicted as a state of 'critical instability', for example in the case of a normative framework that is rich in its conceptual and, as a result, symbolic aspiration, while being under constant threat of being demasked as farcical or worse in light of the unlegitimizable environment its norms have helped

\footnotetext{
${ }^{50}$ Martti Koskenniemi/Paivi Leino, Fragmentation of International Law? Postmodern Anxieties, 15 LEIDEN JOURNAL OF INTERNATIONAL LAW 553 (2002).

${ }^{51}$ Andreas Fischer-Lescano/Gunther Teubner, Regime-Collisions: The Vain Search for Legal Unity in the Fragmentation of Global Law, 25 MiCHIGAN JOURNAL OF INTERNATIONAL LAW 999 (2004); GUNTHER TEUBNER, CONSTITUTIONAL FRAGMENTS. SOCIETAL CONSTITUTIONALISM AND GLOBALIZATION (2012), esp. ch 6, where Teubner analyses the consequences of a constitutional-political analysis arising from regime collisions on a global scale.

${ }^{52}$ In this context, see the program description of "Language and Globalization” at Tilburg University in The Netherlands: http://www.tilburguniversity.edu/research/humanities/language-and-globalization/ (last visited 30 August 2013)

${ }^{53}$ See E.G. CARAYANNIS, InSTITUTIONAL LEARNING AND KNOWLEDGE TRANSFER ACROSS EPISTEMIC Communities, InNOVAtion, TeChnOlOGY, AND KnOWLEDGE MANAGEMENT (2012), esp ch 2 ("Globalization, Nation-States, and Global Governance“), Philip Liste, The Politics of (Legal) Intertextuality, 4 InTERNATIONAL Political Sociology 318 (2010), and Philip LiSTE, VÖLKERRECHT-SPRECHEN. Die KONSTRUKTION DEMOKRATISCHER VÖLKERRECHTSPOLITIK IN DEN USA UND DER BUNDESREPUBLIK DEUTSCHLAND (2012), esp. ch. 1 where Liste highlights the different 'international law' discursive spaces that are opening up between state and non-state actors, regimes, movements, and individuals.

${ }^{54}$ See eg JAMES N. ROSENAU/ERNST-OTTO CZEMPIEL, GOVERNANCE WITHOUT GOVERNMENT: ORDER AND CHANGE IN WORLD GOVERNMENT (1992); IAN AYRES/JOHN BRAITHWAITE, RESPONSIVE REGULATION: TRANSCENDING THE Deregulation Debate (1992); Colin Scott/Fabrizio Cafaggi/Linda Senden (ed.^eds.), The ChallenGE OF

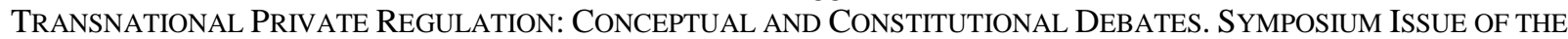
JOURNAL OF LAW AND SOCIETY, Vol. 38, No. 1, pp. 1-188 (2011).

${ }^{55}$ See, for example, Niklas Luhmann, Evolution und Geschichte, in: ders., SOZIOLOGISCHE AUFKLÄRUNG 2150 (1975).
} 
creating. ${ }^{56}$ While this instability of theoretical frameworks which results from internal and external challenges ${ }^{57}$ might be identified and recognized, the necessary 'next' step is often much harder to formulate. Law's relationship to (global) society is one such constellation in which a crisis of law is widely acknowledged, yet nothing like a consensus is emerging in terms of how to respondto that crisis. ${ }^{58}$ Despite this, it is possible to identify a number of thematic clusters which are constantly recurring in related debates about law's status in a global context. These clusters are helpful in distinguishing different dimensions of the law-globalization relationship which the present article seeks to address. Among these clusters we find:

- the state-law nexus and the frequently associated distinction between a (legally structured and operating) state and a (purportedly self-regulatory) society

- the alleged elusiveness of transposing nation state-based concepts such as the 'Rule of Law', 'Separation of Powers' or 'Normative [Constitutional] Hierarchy' into the global sphere [the distinction of domestic and global law]

- the relationship between (formal, institutionalized) law and (informal, 'social') norms [the law/non-law distinction]

- the fate of the concept of 'legitimacy' in an evolving global legal order [the normative status of global law]

- the politics of global law [eg the tension between progressive and conservative endorsements of concepts such as the Rule of Law]

- the legal-philosophical 'foundations' of law in distinction from law seen through the lens of sociological or regulatory theory [the interdisciplinary understanding of law]

The identified clusters underscore the earlier made observation that the relationship of 'law and globalization' is in fact a label for a multi-layered and multi-tiered theoretical analysis of contemporary social order, as formulated from the in itself unstable epistemological position of law. The purposes of the present project are to further investigate the nature of this instability through a series of applications. Part II of the article sets the stage of the following analysis by initiating an investigation into the evolution of law and 'socio-legal studies'. Part III builds on this and looks more closely at one of the currently most vibrant discursive playgrounds in sociolegal studies 'gone global', namely Transnational Law [TL]. TL is here studied above all from a methodological perspective, understanding the emergence of this 'field' as an attempt to make sense of law's doctrinal, conceptual and interdisciplinary adaptations to globalization. The next two parts (IV, V) analyze the role of information and knowledge in the context of this emerging legal-regulatory concept of TL by looking more closely at both 'facts' and 'norms'. The core contention in this part of the article is that while there is an inherently political dimension to the identification and selection of relevant/irrelevant facts on the one hand and the recognition versus dismissal of legal/non-legal norms, on the other, it remains frustratingly difficult to adequately capture or address the nature of this political dimension. It is the ambiguous, illusive

\footnotetext{
${ }^{56}$ Sundhya PAhuJa, DeCOlOnising InTERnATIONAL LAW. DEVELOPMENT, ECONOMiC GROWTH AND THE POLITICS OF UnIVERSALITY (2011); Jothie Rajah, The Gulf Between Promise and Claim: Understanding International Law's Failure to Decolonise, 3 TRANSNATIONAL LEGAL THEORY 285 (2012).

57 ThOMAs S. KuHN, The STRUCTURE OF SCIENTIFIC REVOLUTIONS (1962).

${ }^{58}$ Tim Murphy, Globalization, Legal Pluralism, and the New Constitutionalism, 25 NORDIC JOURNAL OF HUMAN RIGHTS 1 (2007); Neil McCormick, Beyond the Sovereign State, 56 MODERN LAW REVIEW 73 (1993).
} 
nature of both the political status and framework that I am here most interested in, as I am trying to further build on similar insights from other scholars. ${ }^{59}$ Part VI, then, introduces two legal 'fields', 'arenas', 'sub-disciplines' - 'law \& development' on the one hand, 'transitional justice', on the other - which may illustrate how law has become an increasingly interdisciplinary, 'unstable' discipline, the merits of which can be realized only in accepting its unstable nature as an unavoidable consequence from law's engagement with its environment. Part VII deepens this analysis by revisiting the earlier findings regarding the role of knowledge in legal governance, but now scrutinizing the particular role in these two overarching, dynamic areas. Finally, part VIII reiterates the argument for an understanding of TL not as a field, but as a contemporary methodological engagement. This, in consequence, leads to the emergence of a differentiated analytical framework - under the label of 'transnational legal sociology' - with the help of which it might be possible to think further about the connections and intersections between legal doctrine, legal sociology and social sciences in the present era.

\section{STRANGE BEDFOLLOWS, OR: A COHABITATION WITH UNCERTAIN EFFECTS: "SOCIO-LEGAL STUDIES"}

Under the constant nagging at the conceptual citadels of legal coherence and unity ${ }^{60}$ by socialscientific insights, law eventually morphed into an unbound universe of 'socio-legal' studies. Similar to other hybrid scholarly endeavors ${ }^{61}$, the ambiguity of the politics that are at work in the generation, formation and consolidation of such fields results from both conceptualization and impact. The crushing of categories is no longer confined to the internal architecture of a theory, but attains explosive, uncontainable potential in the artificial 'outside'. ${ }^{62}$ The here pursued interest in "translation" is central to such a political perspective on socio-legal studies. Today, however, the translations between different realms and universes of knowledge have become especially complex, as the centrality of purportedly "technical” knowledge in legal norm creation and decision making is likely to complicate otherwise well-reasoned attempts to separate doctrinal from "ethical”, "moral”, "political” dimensions of law. ${ }^{63}$ With this in mind, the article is interested in both the trajectories and the politics of conceptual change in law's efforts to adapt

\footnotetext{
59 TEUBNER 2012, supra, note ___ _ _ LISTE 2012, supra, note

${ }^{60}$ See eg MANFRED BALDUS, DIE EINHEIT DER RECHTSORDNUNG. BEDEUTUNGEN EINER JURISTISCHEN FORMEL IN RECHTSTHEORIE, ZIVIL- UND STAATSRECHTSWISSENSCHAFT DES 19. UND 20. JAHRHUNDERTS (1995), DAGMAR FELIX, EINHEIT DER RECHTSORDNUNG. ZUR VERFASSUNGSRECHTLICHEN RELEVANZ EINER JURISTISCHEN ARgumentationsfigur (1998), and Alexander Hanebeck, Die Einheit der Rechtsordnung als Anforderung an den Gesetzgeber? Zu verfassungsrechtlichen Anforderungen wie "Systemgerechtigkeit" und "Widerspruchsfreiheit" der Rechtsetzung als Maßstab verfassungsgerichtlicher Kontrolle, 41 DER STAAT 429 (2002).

${ }^{61}$ The fitting example often being that of 'cultural studies': see eg Richard Terdiman, Globalization and Cultural Studies: Conceptualization, Convergence, and Complication, XXI COMPARATIVE STUDIES OF SOUTH ASIA, AFRICA AND THE MIDDLE EAST 82 (2001); from the standpoint of legal sociology: David Nelken/Johannes Feest (ed.^eds.), ADAPTING LEGAL CULTURES (2001).

${ }^{62}$ Bruno Latour, From Realpolitik to Dingpolitik, or How to make things public, in: MAKING THINGS PUBLIC. ATMOSPHERES OF DEMOCRACY 14 (Latour/Weibel, eds., 2005); Mariana Valverde, Law's Dream of a Common Knowledge (2003).

${ }^{63}$ On this point, scholars have been offering poignant analysis on the politics of the knowledge-based creation of patent law rules: see, e.g., Laura A. Foster, Critical Cultural Translation: A Socio-legal Methodology for Regulatory Orders, 21 InD. J. GLOB. LEG. STUD. (2014) [this issue], and Kregg Hetherington, Regular Soybeans:

Translation and Framing in the Regulation of a Mega-Crop, 21 IND. J. GLOB. LEG. STUD. (2014) [this issue]
} 
to globalization. As such, our interest must reach beyond the obvious political categorization of assertions that globalization has (rightly ${ }^{64}$ or regrettably ${ }^{65}$ ) put an end to state sovereignty. Instead, the more important task seems to be to better understand the discursive universe in which globalization is associated either with the death of law (as collateral damage from the decline of the state) or the resurgence of law as a flexible regulatory asset in globalizing markets. Such an understanding cannot be gained from a single vantage point. While the analysis of the contested status and role of law in global governance is partly an important concern of sociologists and political scientists, the motivations as well as underlying assumptions that guide regulatory scholars - as de facto political philosophers - in their confidence in law in a domestic context as opposed to the frequently voiced fear of falling into a global void might be better understood through the lenses of (however crude behavioral) psychology ${ }^{66}$ or political philosophy. ${ }^{67}$ But only in a combination of these different disciplinary lenses does it seem possible to arrive at halfway appropriate observations of the emerging global regulatory order. That said, the contention here is that a legal theory of global governance cannot escape its interdisciplinary reformulation, precisely because its categories have come under such close scrutiny.

Meanwhile, the analysis of law's engagement with globalization can rest, at least for the time being, on a number of reference points. One of these is the distinction between 'domestic' and 'international', which - despite its questionable explanatory status in the long run ${ }^{68}$ - serves as a productive framework to identify differently bounded regulatory discourses. Against that background, it is possible to get closer to the 'politics' that accompany the emergence of legal fields, which are in themselves neither 'here' nor 'there', in that they are constantly transgressing the boundaries between the nation-state and the global realm. ${ }^{69}$ Two such fields will be in the centre of the forthcoming analysis, namely the in themselves unruly and seemingly boundaryless fields of Law \& Development and Transitional Justice. By looking more closely at the continuing conceptualization of these areas, including their trials and tribulations as law school curriculum entities, it can be shown how the conflict between progressive and conservative politics, well-known from nation state-based disputes over the aims of legal governance in different regulatory areas, is repeating itself in the transnational arena. ${ }^{70}$ This transnational replay of domestic tensions between progressive versus conservative politics in the global arena

\footnotetext{
${ }^{64}$ Martin Wolf, Why GLOBALIZATION WORKS (2004)

${ }^{65}$ Dieter Grimm, The Achievement of Constitutionalism and its Prospects in a Changed World, in: THE TWILIGHT OF CONSTITUTIONALISM? 3 (Dobner/Loughlin, eds., 2010).

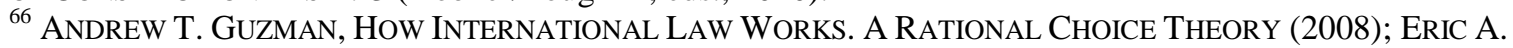
POSNER, THE PERILS OF GLOBAL LEGALISM (2009).

${ }^{67}$ Thomas Pogge, Cosmopolitanism and Sovereignty, 103 ETHICS 48 (1992).

${ }^{68}$ Peer Zumbansen, Administrative law's global dream: navigating regulatory spaces between 'national' and 'international', 11 ICON INTERNATIONAL JOURNAL OF CONSTITUTIONAL LAW forthcoming (2013), 506.

${ }^{69}$ For a beautiful engagement with these boundaries, see David A. Westbrook, Theorizing the Diffusion of Law: Conceptual Difficulties, Unstable Imaginations, and the Effort to Think Gracefully Nevertheless, 57 HARVARD INTERNATIONAL LAW JOURNAL 489 (2006).

${ }^{70}$ For a more extensive analysis along those lines see eg A. Claire Cutler, Artifice, Ideology and Paradox: the Public/Private Distinction in International Law, 4 REVIEW OF INTERNATIONAL POLITICAL ECONOMY 261 (1997); Peer Zumbansen, Sustaining Paradox Boundaries: Perspectives on the Internal Affairs in Domestic and International Law, 15 EUROPEAN JOURNAL OF InTERNATIONAL LAW 197 (2004), and Peer Zumbansen, Transnational Private Regulatory Governance: Ambiguities of Public Authority and Private Power, 76 LAW \& CONTEMPORARY PROBLEMS http://ssrn.com/abstract=2252208 (2013).
} 
can be shown by short-circuiting related debates within the nation-state context on the one hand and within transnational or global governance discourses, on the other. Because the latter is often described as distinctly different from the domestic sphere in light of the absence of a functioning, institutionalized rule of law, a normative-constitutional framework or hierarchy or an adequately designed system of norm-enforcement, the politics of global law are often depicted as being fatally troubled with questions of legitimacy, access to justice, or human rights universalism. Meanwhile, it is within the nation-state that the political dimension of legal theory is most frequently associated with crude demarcations of 'public' versus 'private' spheres of regulatory sovereignty or with claims over contested territory, associated either with state 'interventionism' or societal 'self-regulation'. ${ }^{71}$ Law reconceived as 'socio-legal studies' can be seen as a continuing effort to formulate this dependency of law's meaning (its 'politics') from the context in which it is being evoked. It is this sense of embeddedness that was crucial in the formation of legal sociological analysis of law over time. The task at this point in time is how to adequately capture the challenge arising from law's globalization, how to build on or reject categories and instruments internal to law as a scholarly discipline, how to relate and, possibly, adapt its conceptual framework to other disciplines' insights into the nature of global governance and what lessons to draw from such engagements for law - as a field of doctrine, practice, education and research. $^{72}$

\section{TRANSNATIONAL LAW AS AN ENGAGEMENT WITH GLOBALIZATION}

In a recent chapter for an essay collection on 'Law and Social Theory', Ralf Michaels, a prominent participant in the discussions around 'global legal pluralism' ${ }^{73}$, surmises that globalization has become the definitive framing operative of the 'law of our time'. ${ }^{74}$ An informed, cursory overview of the challenges arising for law and legal theory from globalization - above all law's ties to the concept and the institutions of the Western nation-state - then follows this assumption. At the end of the chapter, Michaels appears to simultaneously dismiss and endorse a reading of 'transnational law' [TL] as a theory or a methodological framework in its own right. ${ }^{75}$ Instead, he suggests that "if anything, transnational law is a description of what we find empirically as law beyond the state, and a theoretical conceptualization of law after the

\footnotetext{
${ }^{71}$ See already the pertinent critique by Robert L. Hale, Coercion and Distribution in a Supposedly Non-Coercive State, 38 POLITICAL SCIENCE QUARTERLY 470 (1923).

${ }^{72}$ On this theme, see the contributions to the Symposium on William Twining's Montesquieu Lecture, 'Globalization and Legal Scholarship', in (2013) 4:3 TRANSNATIONAL LEGAL THEORY, forthcoming.

${ }^{73}$ See, among his previous contributions to the debate: Ralf Michaels, The Re-State-Ment of Non-State Law: The State, Choice of Law, and the Challenge from Global Legal Pluralism, 51 WAYNE LAW REVIEW 1209 (2005); Ralf Michaels, The True New Lex Mercatoria: Law Beyond the State, 14 IndianA JournAL Of GLOBAL LEGAL StUDIES 447 (2007); Ralf Michaels, Global Legal Pluralism, ANNUAL REVIEW OF LAW \& SoCIAL SCIENCE, vol. 5 (also Duke Public LAw \& LEgal TheOry RESEARCH PAPER No. 259) http://papers.ssrn.com/sol3/papers.cfm?abstract_id=1430395 (2009).

${ }^{74}$ Ralf Michaels, Globalization and Law: Law Beyond the State, in: LAW AND SoCIAL THEORY (2nd ed.) forthcoming (http://scholarship.law.duke.edu/faculty_scholarship/2862) (Banakar/Travers, eds., 2013), ms. 1.

${ }^{75}$ Peer Zumbansen, Transnational Comparisons: Theory and Practice of Comparative Law as a Critique of Global Governance, in: THEORY AND PRACTICE OF COMPARATIVE LAW http://papers.ssrn.com/sol3/papers.cfm?abstract_id=2000803 (Bomhoff/Adams, eds., 2012); Peer Zumbansen, Transnational Law, Evolving, in: ELGAR ENCYCLOPEDIA OF COMPARATIVE LAW (2nd ed.) 898 (Smits, ed., 2012 ).
} 
breakdown of methodological nationalism. Transnational law describes a starting point, not an endpoint, of thinking about law." ${ }^{76}$

I take the apparent ambiguity of this position as an expression of a dilemma, which we - as legal scholars and de facto social scientists - are facing almost at every turn in our attempt to adapt the conceptual and theoretical instruments of our discipline to the unruly phenomena of globalization. In turn, 'globalization', as Gunther Teubner noted almost twenty years ago, should rightly be seen as the ultimate deconstructor, which in fact turns every dearly held assumption and foundation of law as a discipline on its head. ${ }^{77}$ As Michaels observes, globalization "has remained a remarkably vague concept in general discourse'. ${ }^{78}$ While this observation seems to be on point when we take into consideration the wide-ranging assessments and appropriations of the term, conceptually, politically, theoretically, ${ }^{79}$ we still must ask: whether the problem is this lack of definition. After all, if it is true, to the least, that 'we are all realists now' (W Singer), why then further invest our energy into definition games. We know well enough that these only raise further questions as to who does the defining, to which purpose and to which effect? In that light, it appears perhaps more productive to embrace the phenomena which are being associated, for a number of reasons, with 'globalization', as challenges to the foundations of established epistemologies and ways of seeing the world. Surely, the ability to "see", and then to "know", in and of itself is neither an asset nor a self-explanatory competence. That much, we ought to have learned. ${ }^{80}$

From such a starting point, Michaels' assertion of TL merely capturing what we "find empirically" can be qualified further to hint at the very problem of how we ought to use frameworks such as a particular theory, an analytical concept or - as in the case of TL - a 'field' within a discipline, to describe (and, to construct) reality. Apart from the question of epistemology and the status of empirical socio-legal studies ${ }^{81}$, the other part of Michaels' statement deserves equal attention, namely where he refers to 'law beyond the state'.$^{82}$ If anything, law's engagement with globalization has been determined by the category of the state and its significance for our understanding of law. That is precisely what Michaels depicts as (the

\footnotetext{
${ }^{76}$ Michaels, supra, note 74 , at 18.

${ }^{77}$ Gunther Teubner, The King's Many Bodies: The Self-Deconstruction of Law's Hierarchy, 31 Law \& Society Review 763 (1997).

${ }_{78}^{78}$ Michaels, supra, note 74, at 1.

${ }^{79} \mathrm{See}$ eg the tensions between accounts offered by Boaventura de Sousa Santos, The Processes of Globalisation, EUROZINE http://www.eurozine.com/pdf/2002 (2002), on the one hand, and MARTIN WOLF, WHY GLOBALIZATION WORKS (2004), on the other.

${ }^{80} \mathrm{See}$ eg Michel Foucault, The Archeology of KnOWLedge (1973), and Bruno Latour, We have neVer BEEN MODERN (CATHERINE PORTER TRANSL.) (1993). See also Lisa Adkins/Celia Lury, What is the Empirical?, 12 EUROPEAN JOURNAL OF SOCIAL THEORY 5 (2009) (discussing the different reasons for a perceived 'crisis' of sociology), on the one hand, and the insightful critique of the ways in which the World Bank has been instrumentalizing empirical data and human rights research, by GALIT A. SARFATY, VALUES IN TRANSLATION: HUMAN RightS AND THE CULTURE OF THE WORLD BANK (2012).

${ }^{81}$ See eg Gunther Teubner/John Paterson, Changing Maps: Empirical Legal Autopoiesis, 7 Social AND LEGAL STUDIES 451 (1998); see for the assessment of legal sociology's contemporary challenges by Thomas Raiser, Sociology of Law in Germany, 11 GERMAn LAW JouRnal 391 (2010), and Peer Zumbansen, Law's Effectiveness and Law's Knowledge: Reflections from Legal Sociology and Legal Theory, 10 GERMAN LAW JOURNAL 417 (2009). ${ }^{82}$ Michaels, supra, note 74, at 1.
} 
need to question and, eventually, overcome) law's 'methodological nationalism'. So far, so good. But, now, where do we 'start', as Michaels suggests at the end of his paper, that we should?

In contrast, I want to suggest that whether or not TL is a theory in its own right or whether legal pluralism [LP], sharing with TL a keen interest in social norms and in the tension between 'law' and 'non-law' ${ }^{83}$, should be seen as helpful ${ }^{84}$, we ought to acknowledge frameworks and approaches such as TL or LP as elements in what Michaels appropriately, in my view describes as a reconstruction, of 'law as social science'. As such, the boundaries of law as a discipline tend to be drawn and redrawn in light of challenges, whose status is inevitably going to be as contested and open for further deconstruction just as the nature of law itself. In other words - but it might just be a theoretically obviously and trite point - there is no fixed point from which it would be possible to treat law as a 'given' and then to analyze how it changes under the influence of outside pressures. The problem of law's boundaries, its content, scope and nature has always already been part of law's definition. Michaels' suggestion to capture the scope of law as it unfolds under conditions of globalization through the study of three determinants or, anchor points - 'territory', 'population/citizenship' and 'government' is well-suited to explore the inchoate ways in which legal categories become intertwined social scientific depictions. Building on these three mini-excursions, we are able to see how a set of reference points that play an important role in law, are revisited and, in turn, reconfigured and expropriated by an immensely rich assembly of non-legal analytics that capture their sociological, philosophical, political, anthropological or geographical dimensions. Again, the ensuing question is what the consequences are for law. That question in itself is new only with regard to the context, in which it is posed. That this context is labeled as globalization suggests that it is a different context from that (of the nation state) in which questions regarding the relationship between law and social developments or, more generally, between law and society, have previously been asked.

Globalization and the various conceptual steps that have been taken by lawyers and socio-legal scholars towards making sense of globalization's impact on law appear to place the investigation on an entirely new and distinct foundation. It is against such a background that we might be able to appreciate the anxiety that shines through proclamations such as "If everything is transnational law, nothing really is." ${ }^{85}$ Michaels qualifies this statement by referring to a use of TL as

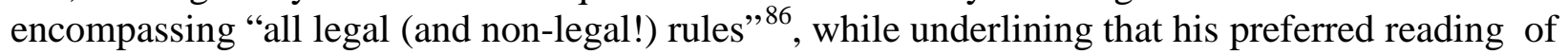
TL, as we alluded to earlier, is one of a description of empirically found instantiations of "law beyond the state" and as a "theoretical conceptualization of law after the breakdown of methodological nationalism." 87

\footnotetext{
${ }^{83}$ Sally Falk Moore, Law and Social Change: the semi-autonomous field as an appropriate subject of study, 7 LAW \& SOCIETY REVIEW 719 (1973)

${ }^{84}$ Compare Michaels, supra, note 74, at 14.

${ }^{85}$ Michaels, supra, note 74, at 18.

${ }^{86}$ Id., [emphasis not added]. See the expression of a similar anxiety in Mauro Zamboni, 'A Legal Pluralist World'... or the Black Hole for Modern Legal Positivism, SSRN http://ssrn.com/abstract=2251017 (2013), available at:

http://ssrn.com/abstract=2251017, ms. 2, referring to the "black hole represented by legal globalization (and its legal pluralism), a black hole where the distinction between law and non-law (i.e. the major tenant of legal positivism and, I would dare say, of the modern Western legal culture) seems to vanish, putting the very existence and legitimacy of the legal phenomenon under question.”

${ }^{87} I d$.
} 
The problem with these qualifications is that they tend to abbreviate and curtail necessary inquiries rather than productively draw on the different already existing investigative strands that have been developing in recent years and that have been benefitting from a increasingly serious engagement across from different disciplinary boundaries. The level of complexity that the work carried out under the label of 'socio-legal studies' has reached at this point, strongly suggests that we should no longer hope for any 'easy scores' or apodictic truths in this theoretical game. In that vein, it is important to point out and to acknowledge that definitions of otherwise unbound, experimental frameworks - such as TL - always carry the risk of inadequately reducing complexity. But, they nevertheless have to be taken seriously as evolutionary steps in theorybuilding that is driven by a coalescence of factors. In the area of legal 'fields', such factors comprise the constant tension between the 'law on the books' and the 'law in action' ${ }^{88}$, the 'exhaustion' of conceptual, analytical and doctrinal categories and instruments in the face of competing interpretations of social 'facts', 89 as well as the recognized need to adapt or expand an existing legal framework to a burgeoning set of technological, social, cultural developments. ${ }^{90}$ Because law that does not adapt to its times, will wither away, we can see these tensions as well as the attempts to address them to have been marking any field of law - including contract, tort, property or civil procedure: all of these have seen such sieges to their citadels of purported coherence and rationality. As keen observers have pointed out for example in the case of private law, the politics of this game of constant change were not first prompted by the emergence of globe-spanning regulatory regimes ${ }^{91}$, but started long before. Against that background, who wants to still define what contract (property, constitutional law etc etc) law really are, aim for and are designed to demarcate, protect and empower?

Transnational law [TL] is just one result of such ongoing attempts to update law and its categorical architecture to fast-moving societal developments. From that viewpoint, the 'body' of TL is driven by the tension as well as by the co-existence of law [legal] and non-law [non-legal rules] as they characterize contemporary regulatory regimes. ${ }^{92}$ But that does not define TL; rather, it is but one element of the concept that gives rise to the field. Understood, instead, as a theoretical platform, or laboratory, TL allows us to study the ways in which this tension actually unfolds, the forms and instances through which this coexistence occurs and the instances where legal categories become infiltrated by meanings from other disciplinary discourses. In other words, TL should be seen as doing the exact opposite of equating or leveling legal and non-legal

\footnotetext{
${ }^{88}$ See eg Roscoe Pound, Law in Books and Law in Action, 44 AMERICAN LAW REVIEW 12 (1910); KARL LLEWELLYN, BRAMBLE BUSH (1928/29) (1950).

${ }^{89}$ Marc Galanter, In the Winter of our Discontent: Law, Anti-Law, and Social Science, ANNUAL REVIEW OF LAW \& SOCIAL SCIENCES 1 (2006); Orly Lobel, The Paradox of Extralegal Activism: Critical Legal Consciousness and Transformative Politics, 120 HARVARD LAW REVIEW 937 (2007)

${ }^{90}$ Sheila JASANOFF, SCIENCE AT THE BAR: LAW, SCIENCE, AND TECHNOLOGY IN AMERICA (1997).

${ }^{91}$ Daniela Caruso, Private Law and State-Making in the Age of Globalization, 39 NEW YORK UNIVERSITY JOURNAL OF INTERNATIONAL LAW \& POLITICS 1 (2006).

${ }^{92}$ Tim Bartley, Institutional Emergence in an Era of Globalization: The Rise of Transnational Private Regulation of Labor and Environmental Conditions, 113 American Journal of Sociology 297 (2007); Tim Bartley, Transnational Governance as the Layering of Rules: Intersections of Public and Private Standards, 12 THEORETICAL INQUIRIES IN LAW Article 6 (2011); Kenneth W. Abbott/Duncan Snidal, Strengthening International Regulation Through Transnational New Governance: Overcoming the Orchestration Deficit, 42 VANDERBILT JOURNAL OF TRANSNATIONAL LAW 501 (2009); Peer Zumbansen, The Ins and Outs of Transnational Private Regulatory Governance: Legitimacy, Accountability, Effectiveness and a New Concept of 'Context', 13 GERMAN LAW JOURNAL 1269 (2012).
} 
rules. The contention is that TL, instead, problematizes the correlation between both normative universes $^{93}$ in that it opens up an increasingly diffused and complex regulatory landscape to a comprehensive assessment of the status and the function of norms (legal or non-legal) inside but also outside legal doctrine. For example, rather than contending that the transnational law merchant - the 'lex mercatoria' encompasses the entire universe of legal and non-legal rules in the field of transnational commercial regulation and governance, TL highlights the interaction between legal and non-legal rules in the governance of transnational societal activity. ${ }^{94}$

\section{The Transnational Law Project Scrutinizes LaW’s ‘Knowledge’ Problem 1: Facts}

This leads us to the second contention: if TL is a framework to investigate the correlation between legal and non-legal norms, then it is not just more, but also something different from a mere 'description' of norms that can empirically be 'found', as alluded to by Michaels. TL problematizes the way in which such finding occurs each time. For example, it is from this perspective that we can recognize the factor of agency in identifying and selecting "applicable" norms in transnational constellations. ${ }^{95}$ Meanwhile, from the perspective of TL it becomes possible to revisit established as well as emerging interpretations of jurisdictional norms: for example, the contested applicability of the U.S. American Alien Tort Statute of $1789^{96}$ in the context of transnational human rights litigation ${ }^{97}$ is squarely situated in the nexus between 'legal' norms and TL's concerns with the identification and interpretation of norms in accordance to the transnational nature of the underlying issues. ${ }^{98}$

A further contention as regards the 'finding' of law's instantiation beyond the state can be made with reference to the ways in which judges in cases - be they domestic or involve transnational reach - distinguish between relevant and irrelevant facts. For example, Judge Posner's opinion in the 2011 Flomo decision is a case in point in that regard. Reviewing the applicability of several ILO conventions to the labor practices 'found' at the Firestone Rubber Plantation in Liberia, Judge Posner at various points acknowledged the lack of sufficient 'information' or 'knowledge' with regard to the labor practices on the ground, but did not hesitate to still decide on the inapplicability of the conventions. ${ }^{99}$ From the perspective of TL the question of the factual

\footnotetext{
93 See the fascinating engagement with these universes by Robert M. Cover, Nomos and Narrative, 97 HARVARD LAW REVIEW 4 (1983); see in this vein, Ino Augsberg, Observing (the) Law: The 'Epistemological Turn' in Public Law and the Evolution of Global Administrative Law, in: REGULATORY HYBRIDIZATION IN THE TRANSNATIONAL SPHERE 11 (Jurcys/Kjaer/Yatsunami, eds., 2013).

94 JAN DALHUISEN, DALHUISEN ON TRANSNATIONAL, COMPARATIVE, COMMERCIAL, FINANCIAL AND TRADE LAW. Volume 1: Introduction - The New Lex Mercatoria and its Sources (2010); EMMANUEL GAILLARD, LEGAL THEORY OF INTERNATIONAL ARBITRATION (2010).

${ }^{95}$ For an illustration of such norm selection in the fields of consumer contract law and corporate governance, see Gralf-Peter Calliess/PeER Zumbansen, Rough Consensus And RunNing Code: A TheORY OF TRANSNATIONAL PRIVATE LAW (2010), pb. 2012, chapters 3 and 4.

9628 U.S. C. $\S 1350$.

${ }^{97}$ For a recent overview, see Chimene I. Keitner, Transnational Litigation: Jurisdiction and Immunities, in: OXFORD HANDBOOK OF INTERNATIONAL HUMAN RIGHTS forthcoming [http://ssrn.com/abstract_224000] (Shelton, ed., 2013).

${ }^{98}$ Arguably, the U.S. Supreme Court's decision of April 17, 2013, has further decreased the likelihood of consolidating a transnational human rights jurisprudence in the tradition of the decision in Filártiga v. Peña-Irala, 630 F.2d 876 (2d Cir. 1980): see Kiobel v. Royal Dutch Petroleum Co., 569 U.S. __ (2013). On Filártiga, see eg William J. Aceves, The Anatomy of Torture: A Documentary History of Filártiga v. Peña-Irala (2007).

${ }^{99}$ Flomo v. Firestone Natural Rubber Co. LL.C., 643 F.3d 1013 (2011), eg at 1023: “They can assure fulfillment by hiring other poor Liberians to help them; and because Firestone's Liberian employees are paid well by local
} 
basis on which decisions regarding the qualification of norms as applicable, non applicable are made is crucial. The importance here lies distinctly no longer alone in the question whether or not a particular ILO convention is applicable, but how the decision of a norm's applicability is shaped by a more comprehensive and adequate understanding of the regulatory regime that in fact governs the scenario on the ground, which gave rise to the "case" in the first place. In other words, the application of a legal norm never occurs in a vacuum, but instead must be seen as an intervention into an already existing normative system, made up of both 'official' and 'inofficial' norms. But, the significance of this rudimentary legal pluralist assertion becomes recognizable even from a cursory look behind the obvious facts in a case. In the example of the rubber plantation at the center of the Flomo decision, one quickly begins to wonder about the consequences for the legal assessment of the case's facts that follow from a consideration of the history of the corporate defendant's almost century-long involvement in the country. ${ }^{100}$ The facts about which the deciding judge recognized to know 'too little' were in fact available, but only if one began to see the case at hand in a broader context, namely in a context that was rich in relevant data and facts. The crucial element of contrasting the case that the Judge had before him with a case 'study' of the actually existing context and environment of the 'case' lies in the recognition of the limits of the epistemological categories that informed the construction of the case. The case study, by contrast, does not simply apply established categories to first depict and then to legally assess the interests found to be in obvious conflict (as, for example, between employee and employer, worker and factory owner, or two contracting parties ${ }^{101}$ ). Instead, its purpose is to highlight the gap between the categories (employee, worker, contractor) and the reality that shapes the case. This gap has been identified as law's legitimacy deficit from a range of theoretical-political viewpoints, with the Interest Jurisprudence's attack on legal positivism in late $19^{\text {th }}$ century Germany ${ }^{102}$ and the Legal Realist attack on legal formalism ${ }^{103}$ merely being early instantiations of such efforts. In the attempt to better understand this context it is necessary to begin to recognize it as being itself the result of both a detailed field study of work and life conditions on the ground and a comprehensive reconstruction of the historical, socio-economic as well as political factors that have shaped the 'conditions' of the existing labor practices. While this dimension encompasses what we might call the political economy of the company's actual operation in the region, the community as well as government and stakeholder relations ${ }^{104}$, what also becomes visible then is how the labor practices at a plantation such as Firestone's in Liberia are shaped by a multitude of regulatory norms that shape the employees', their dependants', and their peers' relations with regard to the company. Without taking into account this reality of these complex relationships between the company and its various stakeholders, a label now attached to a group significantly broader than that encompassing the company's official employees, no adequate assessment regarding the 'labor practices' on the ground can in fact be

\footnotetext{
standards, they can hire helpers cheaply. But alternatively they can dragoon their wives or children into helping them, at no monetary cost; and this happens, though how frequently we don't know." See also ibid.: "We don't know how many supervisors Firestone has deployed on the plantation, and hence whether there are enough of them to prevent employees from using their children to help them. We don't know the supervisors' routines, or how motivated they are to put a stop to any child labor they observe.”

100 See eg CHARLES MORROW WiLSON, LIBERIA (1947), 80ff.

${ }^{101}$ See the pertinent categorization of the interests at stake in Lochner v. New York, 45 U.S. 198 (1905).

102 See R.V. IHERING, DER KAMPF UMS RECHT (1872); IBID., LAW AS A MEANS TO AN END (1913).

103 See the comprehensive treatment by NEIL DUXBURY, PATTERNS OF AMERICAN JURISPRUDENCE (1995).

${ }^{104}$ See eg César Rodríguez-Garavito, Ethnicity.gov: Global Governance, Indigenous Peoples, and the Right to Prior Consultation in Social Minefields, 18 InDIANA JOURNAL OF GLOBAL LEGAL STUDIES 263 (2011).
} 
made. As ethnographic and political science accounts have shown, the regulatory universe of multinational operations in certain locales is itself transnational in its reach and its local effects can only be studied by understanding this complex relation between the local and transnational normative sphere. ${ }^{105}$ Simultaneously, this is the reason why there is never a moment where we can refer to norms that we 'find empirically as law beyond the state'. While, on the one hand, we may identify, collect and categorize norms of different status and quality as shaping a particular regulatory area, the selection and ranking of those norms we find applicable and determinative in a given context, on the other, remains a matter of agency and choice.

\section{The Transnational Law Project Scrutinizes LaW’s ‘KnOWledge’ Problem 2: Norms}

The previous section has ended in a reference to the intersecting local and transnational, official and inofficial, hard and soft norms which characterize regulatory arenas such as contemporary labor governance of multinational companies' operations in the third world. We have applied this lens to commence an investigation into the ways in which the lawyer in such situations can identify, choose and mobilize norms of different origin and status. ${ }^{106}$ A striking feature of this selection process, however, is the effusiveness of the boundaries between (hard or soft) norms and the facts which constitute a social reality. The distinction between actual facts, allegedly standing for an objective materiality or a state of things, and norms and normativity, by which we refer to the idealistic and symbolic dimensions of the world, is always a constructed one: in pointing to a particular 'fact', selections and choices have been made, which ultimately rest on value judgments regarding the status being accorded to the 'facts' in question. ${ }^{107}$

In light of these observations, we now need to further flesh out the proposal in the previous section; the suggestion just made pertained to the development a richer concept of 'context' in order to gain a more adequate understanding of the complex qualities and dimensions of the facts that have given rise to cases such as the transnational human rights litigation in the Bridgestone or Firestone cases. Taking up the just made distinction between political economy and a normative dimension, we now need to ask about the nature of the relationship between both. The here made contention is that the former takes up the challenge of critically investigating the origin, the nature and selectivity of the 'facts' being considered in establishing the factual basis of a case, while the latter refers to the idealization and utopia of fact selection and establishment. The task becomes one of going beyond a narrow reading of the facts, one that is driven by incomplete testimony and typification, while avoiding to be lured down an alluring path that

\footnotetext{
${ }^{105}$ See Tim Bartley, Institutional Emergence in an Era of Globalization: The Rise of Transnational Private Regulation of Labor and Environmental Conditions, 113 AMERICAN JOURNAL OF SOCIOLOGY 297 (2007), for a discussion of the public and private rules governing labor relations; see also David M. Trubek/Jim Mosher/Jeffrey S. Rothstein, Transnationalism and the Regulation of Labor Relations: International Regimes and Transnational Advocacy Networks, LAW AND SocIAL INQUIRY 1187 (2000), and David J. Doorey, In Defense of Transnational Domestic Labor Regulation, 49 VANDERBILT JoURNAL OF TRANSNATIONAL LAW 953 (2010).

${ }^{106}$ Compare Rodriguez-Garavito, supra, note

${ }^{107}$ See eg Bruno Latour, From Realpolitik to Dingpolitik, or How to make things public, in: MAKING THINGS PUBLIC. ATMOSPHERES OF DEMOCRACY 14 (Latour/Weibel, eds., 2005); see also BRUNO LATOUR, WE HAVE NEVER BEEN MODERN (Catherine Porter transl.) (1993), and BRuno Latour, SCIENCE IN ACTION. HOW TO FOLlOW SCIENTISTS AND ENGINEERS THROUGH SOCIETY (1987), in particular chapters 2 and 5; meanwhile, Jürgen Habermas has elaborated a comprehensive and ambitious socio-legal theory based on the critical investigation into the relationship "between facts and norms." See JÜRGEN HABERMAS, BETWEEN FACTS AND NORMS [TRANSL. WILLIAM REHG] (1996).
} 
promises to lead us to what can only be an outrageously unbounded 'history of everything'. In other words, we need to identify the moment when and the ways in which lawyers, litigants and judges lose sight of the relevant facts and instead consolidate a manageable, i.e. justiciable factual basis, which from that point on serves as a complete snapshot of the 'facts of the case'. It is here where lawyers will increasingly benefit from the advances made in anthropological and ethnographic methodological research, given that these areas currently display a forceful commitment to revisit and to scrutinize long established research routines and to update methodologies to new circumstances. ${ }^{108}$ A particular challenge for lawyers arises from the way in which they are now being pressured into acknowledging and processing numerous research that questions law's epistemological basis, but to so without the proper awareness of the historical traits of this inquiry into the factual basis of legal notions. In other words, lawyers today are thrown into a legal sociological discourse that has greatly advanced form its early beginnings and is today no longer merely concerned with the sort of "gap critique" (between law on the books and law in action), as it formed the centre of early $20^{\text {th }}$ century legal sociological analysis. ${ }^{109}$ While much of early legal sociology aimed at showing how judges were prone to ignore both the (socio-economic as well as cultural) basis of legal norms and the effects of legalregulatory intervention ${ }^{110}$, the current reiterations of legal sociological analysis is distinctly more interdisciplinary and encompassing in nature. It is in that sense that we can speak of the challenge of legal sociology 2.0 for the majority of lawyers, who were trained in either the Ehrlichian spirit of recognizing the undeniable parallels between official and in-official regulatory regimes or the Dworkinian mindset with an all-else dismissing focus on legal adjudication as key to unlock law’s mystery. ${ }^{111}$ Moving beyond early legal sociologists' analytical interest in the politics of legal formalism and the rising importance of expert knowledge and scientific governance ${ }^{112}$, intermediate legal sociologists between the 1960 s and 1980s decisively pushed for an interdisciplinary re-orientation of socio-legal studies. ${ }^{113}$ A similar differentiation of a primarily social-justice focused legal critique into an ever expanding series of critical engagements with developments in race, gender, environment, science or international affairs was witnessed among schools of thought with a significant progressive and legal reformist orientation such as the Critical Legal Studies movement. ${ }^{114}$ In comparison, current legal sociology, if it even still exists in the form of designated law school positions or curricular

\footnotetext{
108 See the contributions to Rebecca Hardin/Kamari Maxine Clarke (ed.^eds.), TRANSFORMING ETHNOGRAPHIC KNOWLEDGE (2012), and the monographic study by LindA TUHIWAI SMITH, DECOLONIZING METHODOLOGIES. RESEARCH AND INDIGENOUS PEOPLES (2ND ED.) (2012), in particular ch. 3 "Colonizing Knowledges".

${ }^{109}$ See eg EugEn EhrliCh, FundAMENTAL PrinCIPLES Of THE SOCIOLOGY OF LAW (orig. published in German as GrundLEGUng DER SOzIOLOGIE DES RECHTS, 1913) (1962); Emile Durkheim, The Division of Labor in Society [1893; transl. by W.D. Halls], trans. by Halls (1984).

${ }^{110}$ See eg Max Rheinstein, Review: Two Recent Books on Sociology of Law [reviewing Timasheff's 'Introduction' and Gurvitch's 'Elements'], 51 ETHICS 220 (1941); GEORGES GURVITCH, SOCIOLOGY OF LAW (orig. published in French as PROBLÈMES DE LA SOCIOLOGIE DU DROIT) (1947).

${ }^{111}$ See eg RONALD DWORKIN, LAW'S EMPIRE (1986); in this vein, see Cass R. Sunstein, Lochner's Legacy, 87 COLUMBIA LAW REVIEW 873 (1987).

${ }^{112}$ A good illustration is the account given by JAMES W. LANDIS, THE ADMINISTRATIVE PROCESS (1938).

${ }^{113}$ Erhard Blankenburg/Ekkehard Klausa/Hubert Rottleuthner/Ralf Rogowski (ed.^eds.), ALTERNATIVE RECHTSFORMEN UND AlternATIVEN ZUM RECHT (1980); PHILIPPE NONET/PhILIP SELZNICK, LAW AND SOCIETY IN TRANSITION. TOWARD RESPONSIVE LAW (1978)

${ }^{114}$ Duncan Kennedy, Three Globalizations of Law and Legal Thought: 1850-2000, in: THE NEW LAW AND ECONOMIC DEVELOPMENT 19 (Trubek/Santos, eds., 2006).
} 
components ${ }^{115}$, is prone to form alliances with an increasingly far-ranging array of intersections between law and social, media, behavioral, environmental, indigenous, religious, or cultural studies. While it is impossible to fully capture the potential consequences of this development ${ }^{116}$, it is obvious how the convergence of social science fields that gave rise to hybrid and 'crossover' academic realms such as "cultural” or "media” studies can ultimately leave a discipline such as law untouched.

From this perspective, it appears as if a richer account of the relevant facts in a case will above all depend on a more contextual identification and reading of the data that can be accounted for as being of an explanatory nature for the case at hand. While the bulk of this work still needs to be done in terms of showing how legal sociology 2.0 must now consist of lawyers' serious engagement with the advances in ethnographic research methodology ${ }^{117}$, with the critique of facts and truth in 'science \& technology studies' 118 and with critical historiography as it has become pertinent in selected areas of law. ${ }^{119}$

At the same time, while a more comprehensive approach to an analysis of the facts in a concrete case promises to assist in getting a clearer picture of the actual situation that characterized the conflict between the litigating parties, there will likely always remain a significant gap between a richer factual account of the actual interests and conditions present and the deeper structural frameworks of which a particular conflict scenario is part of. It is here, where for example scholars involved in the so-called Third World Approaches to International Law [TWAIL] have been able to unveil powerful connections between current governance conflicts and historical pathways, political choices and particular historical, socio-economic as well as geo-political circumstances. ${ }^{120}$ Another important development that promises to shed more light on the historically grown dimensions of the context in which many of the currently litigated human rights cases involving multinationals' operations in third world countries are unfolding, is the convergence of 'law \& development' and 'transitional justice'.

\footnotetext{
${ }^{115}$ For an assessment of the relatively sobering institutional state of the discipline, see Thomas Raiser, Sociology of Law in Germany, 11 GERMAN LAW JouRnal 391 (2010), and Marc Galanter, Farther Along, 33 LAW \& SOCIETY REVIEW 1113 (1999).

${ }^{116}$ For a distinctly skeptical assessment from the perspective of law school curricular design, see Anthony D'Amato, The Interdisciplinary Turn in Legal Education, bepress Legal Series. WORKING PAPER 1901. http://law.bepress.com/expresso/eps/1901 (2006).

${ }^{117}$ See HARDIN \& CAMARI ClARKE and SMITH, supra, note _. See also Douglas R. Holmes/George E. Marcus, Cultures of Expertise and the Management of Globalization: Toward the Refunctioning of Ethnography, in: GLOBAL Assemblages: Technology, Politics, and Ethics as Anthropological Problems 235 (Ong/Collier, eds., 2005), and ANNA LOWENHAUPT TSING, FRICTION. AN ETHNOGRAPHY OF GLOBAL GOVERNANCE (2005).

${ }^{118}$ See eg http://sts.cornell.edu/.

${ }^{119}$ See the example of the so-called Third World Approaches to International Law [TWAIL]. See Obiora Chinedu Okafor, Critical Third World Approaches to International Law (TWAIL): Theory, Methodology, or Both?, 10 INTERNATIONAL COMMUNITY LAW REVIEW 371 (2008), and Usha Natarajan, TWAIL and the Environment: The State of Nature, the Nature of the State, and the Arab Spring, 14 OREGON REVIEW OF INTERNATIONAL LAW 177 (2012).

${ }^{120}$ See eg Sundhya Pahuja's critique of the Bretton Woods Institutions‘ embrace of a political sovereignty of postwar nation states without duly recognizing the continuing unfulfilment of economic emancipation and sovereignty: Sundhya PAHUJA, DeCOlONising InTERNATIONAL LAW. DEVELOPMENT, ECONOMIC GROWTH AND the POlitics OF UNIVERSALITY (2011); see for an insightful critique of this analysis, Jothie Rajah, The Gulf Between Promise and Claim: Understanding International Law's Failure to Decolonise’ 3 TRANSNATIONAL LEGAL THEORY 285 (2012); see also Natarajan, previous note.
} 


\section{CONVERGING FIELDS, INTERSECTING EPISTEMOLOGIES}

Law and Development has always been an area which can neither be neatly and clearly defined nor boxed into clear-cut categories. The field has long been a battle field for opposing concepts of law, political and economic order and the role of institutional governance, ${ }^{121}$ and as such has always been a laboratory for audacious experiments with explosive material. Categories such as 'progress', 'development' or 'order' are invariably contentious, and in the context of L\&D are employed as bargaining chips in a high-stakes game over political and economic influence, autonomy and, emancipation. ${ }^{122}$ While specific local contexts of L\&D became the loci of such contestation, often enough under the magnifying glass of international and national development agendas, market integration and state reform, one of the most striking discoveries to be made here relates to the fact that the contentious items in the L\&D context are also those which have long informed a critical analysis of law and governance in the context of the nation state. ${ }^{123}$ As such, the boundaries between the developing and the developed world, between those countries receiving and those exporting or providing legal (or economic) aid become porous, and a legal theory of L\&D can fruitfully build on its older domestic sister.

Among the important scholarly projects pursued by L\&D scholars has been the discovery and analysis of the legal pluralist nature of the governance orders in the context of development. ${ }^{124}$ With a growing awareness of the different, existing ordering structures 'on the ground' in the development context came the realisation that any legal order challenges the observer to acknowledge the parallels between and the co-existence of formal and informal, hard and soft law, of legal and non-legal norms. ${ }^{125}$ This realisation prompted L\&D scholars to acknowledge but also to build on the idea that many of the challenges pertaining to a law/non-law distinction that had been identified as specific to the development context, were in fact detachable from any legal governance framework. Indeed, the inadequacy of existing legal governance thinking pointed to the need for a different theoretical — but also, doctrinal — attention. ${ }^{126}$

It is this realisation that allows for a better appreciation of the questionable foundations of a legal 'order', of the embeddedness of legal governance in a particular institutional setting (eg, the

\footnotetext{
${ }^{121}$ David Kennedy, Laws and Development, in:, LAW AND DEVELOPMENT: FACING COMPLEXITY IN THE 21ST CENTURY - Essays In HonOuR OF PETER SlinN 17 (J. Hatchard and A Perry-Kessaris eds., 2003), 17

${ }^{122}$ For a brilliant deconstruction of the post-war conceptual division between political and economic emancipation of former colonial states, see PAHUJA, supra, note

${ }^{123}$ The masterful analysis is still David Trubek/Marc Galanter, Scholars in Self-Estrangement: Some Reflections on the Crisis in Law and Development Studies in the United States, WisConsin LAW REVIEW 1062 (1974).

${ }^{124}$ Katharina Pistor and Daniel Berkowitz, Of Legal Transplants, Legal Irritants, and Economic Development, in: CORPORATE GOVERNANCE AND CAPITAL FlOWS IN A GlOBAL ECONOMY 347 (Peter Cornelius and Bruce Kogut eds., 2003); Katharina Pistor, The Standardization of Law and Its Effect on Developing Economies, 50 AMERICAN JOURNAL OF COMPARATIVE LAW 97 (2002)

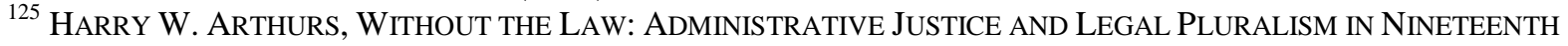
CEnTURy ENGLAND (1985); Roderick A. Macdonald and J MacLean, No Toilets in Park, 50 MCGILl LAW Journal 721 (2005); Sally Falk Moore, Law and Social Change: The Semi-Autonomous Field as an Appropriate Subject of Study, 7 LAW \& SOCIETY REVIEW 719 (1973)

${ }^{126}$ Macdonald and MacLean, supra, note__. See also Craig Scott, A Core Curriculum for the Transnational Legal Education of JD and LLB Students: Surveying the Approach of the International, Comparative and Transnational Law Program at Osgoode Hall Law School, 23 PenN State InTERnAtional LAW REVIEW 757 (2005).
} 
'state') and at a particular moment in (geo-political) time. ${ }^{127}$ To the degree that the struggle over law 'reform' in the context of development is seen as not entirely removed from contestations of legal (political, economic) order in the domestic context, L\&D emerges as a field, which is just as much concerned with the relationship of law to its (particular, local) social environment and context as that has been the case for any other legal theoretical or legal sociological inquiry. ${ }^{128}$ But, accepting this perspective also implies accepting the loss of an outside observer's standpoint. Precisely, by acknowledging the inseparability of critical legal analysis in the domestic and the 'development' context, we lose the comfort of being 'outside' of the sphere which we are purporting to study and to examine in a disinterested manner. ${ }^{129}$ Instead, the demarcation of the L\&D context from that of one's home legal system and jurisdiction becomes questionable in itself, because the assertions of law's precariousness in the development context apply to the domestic home context with equal force. On that basis, the distinction between governance challenges 'there' and 'here' appears artificial. Indeed, the distinction seems designed to insulate the domestic context from critique while depicting the development context as deficient and requiring 'aid' and assistance. The identification of a series of legal governance questions as arising from within the context of a 'developing country' inevitably leads to these questions having to be seen as already pertinent much 'earlier', namely already present and evident in the context of domestic legal critique.

A striking feature of this contextualisation of $L \& D$ as part of a larger exercise in investigating law's relationship to and role in society, is the way, in which the field opens itself up to an engagement and exchange with complementary discourses about regulatory places and spaces. Both legal scholars ${ }^{130}$ and sociologists ${ }^{131}$ have been scrutinising the conceptual and constituted nature of such regulatory spaces; spaces which escape a straight-forward depiction from a single discipline's vantage point. Just as this critique has become pertinent with regard to the analysis of different, specialised regulatory arenas, ranging from labour ${ }^{132}$ to corporate, ${ }^{133}$ from

\footnotetext{
${ }^{127}$ Begoña Aretxaga, Maddening States 32 AnNUAL REVIEW OF ANTHROPOLOGY 393 (2003)

${ }^{128}$ Roger Cotterrell, Why Must Legal Ideas Be Interpreted Sociologically? 25 JoURNAL OF LAW \& SOCIETY 171 (1998); Reza Banakar, Law Through Sociology's Looking Glass: Conflict and Competition in Sociological Studies of Law in THE ISA HANDBOOK IN CONTEMPORARY SOCIOLOGY (A Denis and D Kalekin-Fishman, eds., 2009); Zumbansen, Law's Effectiveness, supra, note

${ }^{129}$ David M. Trubek and Marc Galanter, Scholars in Self-Estrangement, supra, note__. See also Trubek, Toward a Social Theory of Law: An Essay on the Study of Law and Development 82 YALE LAW JOURNAL 1 (1972)

${ }^{130}$ Richard T. Ford, Law's Territory (A History of Jurisdiction) 97 MiCHIGAN LAW REVIEW 843 (1999)

${ }^{131}$ Saskia Sassen, The State and Globalization, in: GovernANCE IN A GLOBALIZING WorLD 91(JS Nye and JD Donahue eds., 2000); ibid., The Places and Spaces of the Global: An Expanded Analytic Terrain, in:

GlobAlizATION THEORY. ApProACHES AND CONTROVERSIES 79 (David Held and Andrew McGrew eds., 2007); David Harvey, The Sociological and Geographical Imaginations, InTERNATIONAL JOURNAL OF POLITICS, CULTURE AND SOCIETY 211 (2005)

132 David M. Trubek, Janet Mosher and JS Rothstein, Transnationalism and the Regulation of Labor Relations, supra, note__ ; Guy Mundlak, De-Territorializing Labor Law 3 LAW \& ETHICS OF HuMAN RIGHTS 188 (2009); Harry W. Arthurs, Extraterritoriality by Other Means: How Labor Law Sneaks across Borders, Conquers Minds, and Controls Workplaces Abroad , 21 STANFORD LAW \& POLICY REVIEW 527 (2010)

${ }^{133}$ Larry Catá Backer, Private Actors and Public Governance Beyond the State: The Multinational Corporation, the Financial Stability Board, and the Global Governance Order, 18 InDIANA JOURNAL Of GLOBAL LEGAL STUDIES 751(2011); Peer Zumbansen, Neither "Public" nor "Private", "National” nor "International”: Transnational Corporate Governance from a Legal Pluralist Perspective 38 JOURNAL OF LAW \& SOCIETY 50 (2011)
} 
environmental ${ }^{134}$ to criminal law, ${ }^{135}$ altogether suggesting a methodological shift away from comparative and towards transnational law, ${ }^{136}$ L\&D has become a very active laboratory for a renewed engagement with a critical and contextual analysis of law in a fast-changing and volatile environment.

This aspect has been underlined, perhaps most tellingly, by the recent approximation of L\&D with the field of 'transitional justice' [TJ], which testifies to an increasing awareness among interested experts of the close connections between investigations into the 'legacies' of past injustices with programs of future-directed legal and economic aid. ${ }^{137}$ Closely connected to and oftentimes overlapping with this very vivid scholarly engagement has, of course, been an equally vibrant 'literary' 138 and cultural engagement with 'transition' periods. After the seminal (inevitably colonial) portrayals by Joseph Conrad in 'An Outpost of Progress' (1897) or 'Heart of Darkness’ (1899), 'post-colonial’ novels such as Chinua Achebe’s 'Things Fall Apart’ (1958) or JM Coetzee's 'Waiting for the Barbarians' (1980) again poignantly scrutinised the slippery slope between 'us' and 'them' that inescapably pervades any 'intervention' or 'development' context. How in the context of public international law's attempts to address transnational military and civil conflict, this slope has become painfully obvious again, was powerfully illustrated in Anne Orford's critique of the hidden, hegemonic aspirations of recent instances of 'humanitarian intervention'. ${ }^{139}$ Excavating the challenges of concepts such as 'change', 'reform' and 'progress', as they have been central to seminal transitional justice debates as those concerning South Africa ${ }^{140}$ or Sri Lanka, ${ }^{141}$ Achmat Dangor's 'Bitter Fruit' (2001) or films such as Vithanage's 'Death on a Full Moon Day', have become inseparably intertwined with the scholarly, 'expert' discourse around these instances of transitional justice.

\footnotetext{
${ }^{134}$ L Gulbrandsen, S Andresen and JB Skjærseth, Non-State Actors and Environmental Governance: Comparing Multinational, Supranational and Transnational Rule Making, in: THE ASHGATE RESEARCH COMPANION TO NONSTATE ACTORS (B Reinalda ed., 2011), 463; N Craik, Deliberation and Legitimacy in Transnational Environmental Governance, IILJ WORKING PAPER 2006/10, NEW YORK UNIVERSITY, GLOBAL ADMINISTRATIVE LAW SERIES; Charis Kamphuis, Canadian Mining Companies and Domestic Law Reform: A Critical-Legal Account, 13 GeRMAN LAW JouRnAL 1456(2012); Sara Seck, Home State Regulation of Environmental Human Rights Harms As Transnational Private Regulatory Governance, 13 GERMAN LAW JOURNAL 1360 (2012).

${ }^{135}$ Neil Boister, Transnational Criminal Law? 14 EUROPEAN JOURNAL OF INTERNATIONAL LAW 953 (2003); NeIL BOISTER, AN INTRODUCTION TO TRANSNATIONAL CRIMINAL LAW (2012); RJ CURRIE, INTERNATIONAL AND TRANSNATIONAL CRIMINAL LAW (2010).

${ }^{136}$ Craig M. Scott, ‘Transnational Law’ as Proto-Concept: Three Conceptions, 10 GERMAN LAW JouRnAL 859 (2009); Peer Zumbansen, Transnational Legal Pluralism, 1 TransNATIONAL LEgAL THEORY 141(2010); ibid., Transnational Law, Evolving, in: ELGAR ENCYCLOPEDIA OF COMPARATIVE LAW 898 (2ND ED., Jan Smits ed., 2012). ${ }^{137}$ See, e.g., Rani Mani, Dilemmas of Expanding Transitional Justice, or Forging the Nexus between Transitional Justice and Development 2 INTERNATIONAL JOURNAL OF TRANSITIONAL JUSTICE 253(2008), and the contributions to Pablo De Greiff and Roger Duthie eds., Transitional Justice and DeVELOPMENT: MAKING ConNECTIONs (2009). See also the forthcoming collection Ruth Buchanan and Peer Zumbansen eds., LAW IN TRANSITION: DEVELOPMENT, RightS AND TRANSitional Justice (Oxford, Hart Publishing, 2013, with an epilogue by Bryant Garth).

${ }^{138}$ See the insightful discussion of the prose/poetry debate in India around the work of Rabindranath Tagore, in Dipesh CHAKRABARTY, PROVINCIALIZING EUROPE: POSTCOLONIAL THOUGHT AND HisTORICAL DifFERENCE, $\left(2^{\text {nd }}\right.$ ed., 2007).

${ }^{139}$ Anne Orford, Muscular Humanitarianism: Reading the Narratives of the New Interventionism 10 EUROPEAN JOURNAL OF INTERNATIONAL LAW 679 (2003)

${ }^{140}$ Hugh Corder, Prisoner, Partisan and Patriarch: Transforming the Law in South Africa 1985-2000 118 THE SOUTH AFriCAN LAW JOURNAL 772(2002); Aeyal Gross, Reconciliation in South Africa 40 STANFORD JouRnaL OF INTERNATIONAL LAW 40 (2004)

141 J DERGES, RituAL AND RECOVERY IN POST-CONFLICT SRI LANKA (2012)
} 
But, what can this intersection of scholarly, literary, and cultural engagement tell us about the methodological challenges arising in the L\&D (and, transitional justice) context? To the degree that we can already build on a host of critical work to scrutinise the orientation, method, and contentions of L\&D and TJ theory, an additional aspect of this enterprise concerns the acknowledgement of and engagement with non-scholarly content. Another question concerns the demarcation of places and spaces in this context. What, we may ask, distinguishes the focus of Achmat Dangor's poignant analysis of family relations in post-Apartheid South Africa ${ }^{142}$ from the haunting account of Mourid Barghouti's return to Palestine after an involuntary 30-year exile? ${ }^{143}$ Emerging, from these accounts, is a powerful illustration of what we might call the 'transnational human condition', marked by multilayered and multi-tiered relations of belonging and 'citizenship'. It is this dimension of the 'human condition' that could arguably be seen as the fourth dimension of Hannah Arendt's depiction of labour-work-action, ${ }^{144}$ scrutinising the possibilities of political, social belonging in a post-national environment, which is marked by the fragility of political communities and, again, an increased precariousness of political voice. ${ }^{145}$

Chinua Achebe, the author of the seminal novel 'Things Fall Apart' (1958), recounts in his 2009 collection of short stories, 'The Education of a British-Protected Child', numerous instances in which he and the audiences he speaks before, are confronted with the porosity of the lines that divide 'home' and 'abroad', the 'here' and the 'there'. In Achebe's rendering, these experiences illustrate the tensions in people's lives when trying to make sense of their deeply felt attachments to places of origin, places of meaning, when - at the same time - they find themselves on an inchoate and often swirling trajectory, which takes them through different places, communities, spheres of interaction, places of engagement and confrontation - with others, who have come to these places through similar patterns of predictable unpredictability. Achebe's stories recount numerous instances of frustration in the face of alienation, cliché and stereotype that seem to repeat themselves - over and over again. The author presents them in an uncompromisingly and tirelessly analytical manner, the various accounts underlining the importance of difference in that which seems to be the same, the varying conjectures of people's meetings, confrontations and clashes of viewpoints and observations that cannot be so simply traced back, as emerges from story to story, to one particular stance, one easily demarcated political viewpoint or a comprehensively founded moral choice. Instead, Achebe highlights the numerous cross-roads in people's perceptions and judgments, the complex overlapping of context and intent that shape the moment where one formulates and utters one's view. He seems to say 'Look again', 'Think again' and 'Look again', and it is this back and forth wandering of our gaze, which may help to better grasp the challenges in contemporary L\&D and TJ contexts. These contexts are intricately marked by the simultaneous existence of the 'new' and the 'old'. And yet we are asked to reject this (overly neat) juxtaposition for the ways in which it imposes an evolutionary narrative of progress onto a sphere that needs to be studied through its complex relationship between local

\footnotetext{
142 ACHMAT DANGOR, BITTER FRUIT (2001)

${ }^{143}$ M BARGHOUTI, I SAW RAMALLAH (2004)

${ }^{144}$ HANNAH ARENDT, THE HumAN CONDITION (1958)

145 See Roger Cotterrell, Spectres of Transnationalism: Changing Terrains of Sociology of Law 36 JOURNAL OF LAW AND SOCIETY 481 (2009), and NANCY FRASER, SCALES OF JUSTICE: REIMAGINING POLITICAL SPACE IN A GLOBALIZING WORLD (2009).
} 
and global consciousness. ${ }^{146}$ Similarly, both L\&D and TJ become mere instantiations of a renewed effort to reflect critically on the methodological basis of legal-political governance.

As such, both L\&D and TJ can be seen as efforts undertaken from within law as scholarly discipline and practical endeavour to illustrate how law is constantly prompted to adapt to its changing environment - both substantively and normatively. This adaptation of law occurs in often unmapped, unchartered and undomesticated 'spaces'. As in Achebe's accounts, these spaces are both geographical and intellectual, both real and constructed. And, as is highlighted by the scholarship in the areas of $L \& D$ and $T J$, the critical engagement with these allegedly dividing lines between 'real' and 'constructed', between, say, field work, empirical data, news reports and statistics on the one hand and description, critique, deconstruction, and argument, on the other, are at the core of what these two 'fields' are really all about. To both emphasise and simultaneously question the categories by which we draw lines between 'here' and 'there', 'home' and 'abroad', 'ours' and 'theirs', becomes an existential question for law and for the lawyer employing its label and toolkit. Seen, studied, theorised and practiced in this critical way, L\&D and TJ become instantiations of a much more comprehensive engagement with the 'concept of law', with the categories by which in research and curriculum lines are drawn between 'domestic' and 'foreign' laws and legal cultures. Thus, the scholarship of L\&D and TJ of such ambitious calibre is likely perceived as a threat to the standards and routines of parochially focused scholarship as it still dominates law reviews and conferences and as it, in myriad ways, continues to influence and shape law school course design and the programming of legal education. The particular approach here taken to defend L\&D and TJ as both critical engagements with and representations of contemporary law threatens the daily routine of law schools that profess to teach their fee-paying clients to 'learn to think like a lawyer': the here embraced approach critically challenges this entire routine and suggests that it could all be in fact very different if only we cared to reflect more on the connections between 'here' and 'there'. In other words, are the legal conflicts we are concerned with domestically really so much different from the ones we identify in 'foreign' places? If that is true, then the question is how we can develop an adequate epistemological framework for law in a transnational context. As is clear from Achebe's stories, to think about these connections is a tiresome business, one that must remain cautious, self-critical and never-satisfied, one that continues to draw on a wide spectrum of information, data, accounts - in other words, on a complex body of 'knowledge', on which one draws and to which one already and constantly contributes.

\section{The CRUCiAl Role of KNOWLEDGE IN DEVELOPMENT AND TRANSITIONAL JUSTICE}

The vibrant and increasingly intersecting intellectual discourses around the conceptual and normative foundations of $\mathrm{L} \& \mathrm{D}^{147}$ and of $\mathrm{TJ}{ }^{148}$ are increasingly complemented and contextualised by a critical engagement with the North's ${ }^{149}$ legal regulatory as well as

\footnotetext{
${ }^{146}$ CHAKRABARTY, PROVINCIALIZING EUROPE, supra, note ch. 5 'Birth of the Subject'.

${ }^{147}$ See the contributions to David M. Trubek and Alvaro Santos eds., THE NEW ECONOMIC LAW AND DEVELOPMENT (2006).

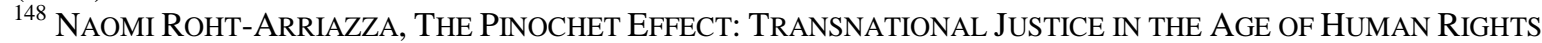
(2005); Naomi Roht-Arriazza and J Mariezcurrena eds., TRANSITIONAL JUSTICE IN THE TWENTY-FIRST CENTURY: Beyond TRUth Versus JustiCE (2006); Rosemary Nagy, Transitional Justice as Global Project: Critical Reflections 29 THIRD WORLD QUARTERLy 275 (2008); S Vieille, Transitional Justice: A Colonizing Field?, 4 AMSTERDAM FORUM 58 (2012)

149 This depiction is used to mark both economic and ideological characteristics rather than a geographic region.
} 
epistemological interventions in the 'South' ${ }^{150}$ Arising from this attention to L\&D and TJ is an intensified interest in the nature of knowledge implicated in these different engagements. Knowledge becomes a crucial variable as it applies to a host of divergent conceptual and normative programs. For example, knowledge is at the heart of the expertise and 'know-how' retained by a governing body or drawn upon by governmental actors when crafting regulatory instruments and interventions. ${ }^{151}$ At the same time, knowledge as a variable and an unknown enters both sides of regulatory interventions - pertaining to what the regulator knows and what is known within the sphere acted upon. This double contingency of what law should know but can never know for certain, has long been a concern of legal regulatory theory, and of legal sociology and criminology in particular. ${ }^{152}$ Given the complex interplay of domestic and transnational governance discourses and the centrality of knowledge in both, ${ }^{153}$ the intensified interest in scrutinising what we know when unleashing programs of aid, reform as well as 'technical' and legal assistance has to be central to any future engagement with L\&D and TJ as part of a larger, interdisciplinary theory of global governance. ${ }^{154}$ From the vantage point of a critical engagement with knowledge, such an enterprise must develop a methodology able to open up, rather than eclipse avenues of contestation and mutual learning. ${ }^{155}$ We can already see, how the parallels and shared interests in contemporary L\&D and TJ discourses are echoed by the connections between domestic and transnational governance discourses. Where we find that L\&D discourses are inseparably intertwined with TJ-related questions regarding the appropriate and non-universalising, ${ }^{156}$ legal/non-legal response to legacies of suppression, exploitation and domination, we are confronted with the co-evolutionary dynamics of legal/non-legal, hard/soft, formal/informal. In short, attending to knowledge points us to the legal pluralist of modes of governance characteristic in settings which we have hitherto tended to study through conventional notions of jurisdiction, that is, through legal spatial lenses. ${ }^{157}$ However, these co-

${ }^{150}$ Boaventura de Sousa Santos, Beyond Abyssal Thinking: From Global Lines to Ecologies of Knowledge, EUROZINE, 29 June 2007. See also the contributions to Boaventura de Sousa Santos ed., ANOTHER KNOWLEDGE IS POSSIBLE: BEYOND NORTHERN EPISTEMOLOGIES (2007), and Radha D’Souza, Imperial Agendas, Global Solidarities, and Third World Socio-legal Studies: Methodological Reflections 49 OsgOODE HALL LAW JouRnaL 409 (2012).

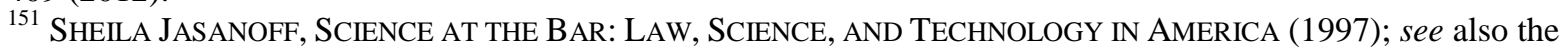
contributions to G Edmond ed., EXPERTISE IN REGULATION AND LAW (2004).

${ }^{152}$ Karl N. Llewellyn, The Normative, the Legal, and the Law-Jobs: The Problem of Juristic Method 49 YALE LAW JouRnal 1355 (1940); Niklas Luhmann, Some Problems with Reflexive Law, in: STATE, LAW AND ECONOMY AS AuTOPOIETIC SYSTEMS (G Teubner and A Febbrajo eds., 1992) 389; Zumbansen, Law's Effectiveness, supra, note

${ }^{153}$ Kenneth W. Abbott and Duncan Snidal, Strengthening International Regulation Through Transnational New Governance: Overcoming the Orchestration Deficit, 42 VANDERBILT JOURNAL OF TRANSNATIONAL LAW 501(2009); Zumbansen, The Ins and Outs of Transnational Private Regulatory Governance: Legitimacy, Accountability, Effectiveness and a New Concept of "Context" 13 GeRman LAW JouRnal 1269 (2012)

${ }^{154}$ David Held, Reframing Global Governance: Apocalypse Soon or Reform! In: GLOBALIZATION THEORY: APPROACHES AND CONTROVERSIES (David Held and Andrew McGrew eds., 2007) 240; Fleur E. Johns, Global Governance: An Heretical History Play, 4 GlOBAL JuRIST AdVANCES Art. 3, (2004)

${ }^{155}$ See, eg, Jan Niels Pieterse, Globalization North and South: Representations of Uneven Development and the Interaction of Modernities 17 THEORY, CULTURE \& SOCIETY 129(2000); M-R Trouillot, The Anthropology of the State in the Age of Globalization: Close Encounters of the Deceptive Kind, 42 CURRENT ANTHROPOLOGY 125 ; James Ferguson and Akhil Gupta, Spatialising States: Toward an Ethnography of Neoliberal Governmentality 29 AMERICAN ETHNOLOGIST 981 (2002)

${ }^{156}$ S Vieille, Transitional Justice: A Colonizing Field? 4 AMSTERDAM FORUM 58(2012).

${ }^{157}$ Ferguson and Gupta, supra, note___ Achille Mbembe, At the Edge of the World: Boundaries, Territoriality, and Sovereignty in Africa 12 PUBLIC CULTURE 259 (2000) 
evolutionary dynamics between L\&D and TJ support the emergence of regulatory regimes which can no longer adequately be captured through categories of state sovereignty or jurisdiction. Instead, the emerging transnational regulatory landscape follows to a large degree the fragmenting dynamics of a functionally differentiated world society, prompting, in turn, an intensified investigation as to the legitimacy, that is, the normative and political implications of the systems theory's world society model. ${ }^{158}$

These debates provide a formidable background to the continuously evolving debate around L\&D in that they complement and expand the highly charged economic and political stakes in this arena. 'Knowledge' occupies a crucial place in L\&D scholars' longstanding, persistent engagements with bridging both national and development governance discourses. ${ }^{159}$ Taking a closer look at the role of knowledge in the L\&D context promises important insights into the future trajectory of this field in the above-sketched context of interdisciplinary global governance studies. What drives and motivates developments such as the World Bank's self-description as a 'Knowledge Bank' ${ }^{\text {'60 }}$ becomes a matter of critical concern, and prompts our reflection on the origins as well as the experiences that have already been made with such data-driven governance approaches in other places and times. In other words, the question regarding the role of knowledge in today's development agendas - in theory and practice - invites us to take a closer look at the connections and differences between the prominence of knowledge in this context and in domestic contexts in the past. To do so seems especially opportune in light of the crudeness of assertions, distinctions and categories that continue to characterise global governance discourses; particularly in terms of the descriptions and analysis of constellations that really deserve a more comprehensive and sophisticated conceptual treatment. ${ }^{161}$ Indeed, the persistence of inadequate analytic categories in the field of global governance is at considerable odds with contemporary analysis of knowledge-driven governance. ${ }^{162}$ Knowledge as an analytic category offers us a way forward.

The overriding challenge arising from a critique of knowledge in the development context, however, consists in the question of frame of reference. Every employed conceptual, analytical and doctrinal toolkit itself has a history of its own, the way it came to be put together, the order of instruments that are stored and arranged on its inside, and the use that has been made of them over time. The L\&D context in particular prompts a host of questions regarding the origin, adequacy and transferability of regulatory models. Similar to the seemingly never-ending self-

\footnotetext{
158 This tension characterises the interchange between, say, Gunther Teubner and Emilios Christodoulidis. See Gunther Teubner, Fragmented Foundations: Societal Constitutionalism beyond the Nation State, in: The Twilight of Constitutionalism? (Petra Dobner and Martin Loughlin eds., 2010) and the contributions by Emilios Christodoulidis, Gert Verschraegen, Bart Klink, and Wil Martens in NetherLANDS Journal OF LEGAL PhILOSOPHY (2011). For Gunther Teubner's most recent, comprehensive attempt to engage with the challenge of normativity, see his monograph, Gunther Teubner, CONSTITUTIONAL FRAGMENTS, supra, note

${ }^{159}$ David Trubek, Toward a Social Theory of Law: An Essay on the Study of Law and Development, 82 YALE LAW JOURNAL 1 (1972); David Trubek/Marc Galanter, Scholars in Self-Estrangement: Some Reflections on the Crisis in Law and Development Studies in the United States, WISCONSIN LAW REVIEW 1062 (1974)

160 http://siteresources.worldbank.org/WBI/Resources/KnowledgeBankOct2004.pdf

161 Richard A. Posner, Creating a Legal Framework for Economic Development 13 THE WORLD BANK RESEARCH OBSERVER 1 (1998)

${ }^{162}$ Karl-Heinz Ladeur, Constitutionalism and the State of the "Society of Networks": The Design of a New "Control Project” for a Fragmented Legal System 2 TRANSNATIONAL LEGAL THEORY 463(2011)
} 
inspection and critique of comparative law, ${ }^{163} \mathrm{~L} \& \mathrm{D}$ is a field forever belaboured and challenged on a complex methodological basis, which underscores the relevance of approaching a study of a local regulatory culture from a more comprehensive perspective, eventually allowing for a scrutiny of the actors, norms and processes, which shape the development context. ${ }^{164}$ But, how are we to account for inevitable baggage and background assumptions, that accompany and shape the governance as well as desired policy ideas transplanted from one context — which in the $20^{\text {th }}$ century L\&D context has been the post-Industrialist and post-Welfare constitutional state $^{165}$ — into another context with institutional and normative dimensions which we might not be able to map with the cartography we are used to. This seems to be of particular importance with regard to the implicit assumptions informing an endorsement of regulatory models such as decentralisation, innovation and regulatory competition. In political and regulatory theory discourses of the last two to three decades, these terms emerged in an intricate intellectual space between economic and political theories and have by now attained an almost sacrosanct character, be that with regard to federal structures in complex polities ${ }^{166}$ or in the context of searching for growth models in path-dependent economies. ${ }^{167}$ However, as examples of transatlantic transplants already illustrate, the effects of policies that endorse a fine-tuned subsidiarity-federalist framework and that place hope into the regulated self-regulatory dynamics of actors on different levels ${ }^{168}$ greatly depend on the historically and politically evolved context in which they are implemented. What might be in itself a very promising conceptual approach to the study of multi-level and multi-polar regulatory systems — and the EU certainly represents just that ${ }^{169}$ — will eventually unfold through highly intricate and unpredictable dynamics in a continuously evolving complex environment. ${ }^{170}$

\footnotetext{
163 See now the contributions to Maurice Adams and Jacco Bomhoff eds., PRACTICE AND THEORY IN COMPARATIVE LAW (2012).

${ }^{164}$ For more background on the A-N-P approach, see Zumbansen, Lochner Disembedded, supra, note

${ }^{165}$ Ross Cranston, Legal Foundations of the Welfare State (1985); Francis G. Castles (ed.^eds.), The

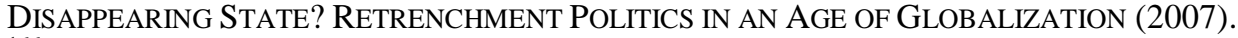

${ }^{166}$ Susan Rose-Ackerman, Risk Taking and Reelection: Does Federalism Promote Innovation? 9 JOURNAL OF LEGAL STUdIES 593(1980); George A. Bermann, Harmonization and Regulatory Federalism, in: HARMONIZATION OF LEGISLATION IN FEDERAL Systems (Ingolf Pernice ed., 1996); Robert Howse and Kalypso Nicolaidis eds., THE FEDERAL VISION (2001); B Galle and J Leahy, Laboratories of Democracy? Policy Innovation in Decentralized Governments, 58 EMORY LAW JOURNAL 1333 (2009)

${ }^{167}$ William Lazonick, Varieties of Capitalism and Innovative Enterprise 24 COMPARATIVE SOCIAL RESEARCH 21(2007); Johann Peter Murmann, KnOWledge And Competitive AdVANTAge: The Coevolution OF FiRMS, TECHNOLOGY AND NATIONAL INSTITUTIONS (2003).

${ }^{168}$ Charles F. Sabel and Jonathan Zeitlin, Learning from Difference: The New Architecture of Experimentalist Governance in the EU 14 EUROPEAN LAW JOURNAL 271(2008); see already Michael C. Dorf and Charles F. Sabel, A Constitution of Democratic Experimentalism, 98 COLUMBIA LAW REVIEW 267(1998).

169 See G Majone, The European Commmunity Between Social Policy and Social Regulation 31 JOURNAL OF COMmOn MARKet Studies 153(1993), and Kenneth A. Armstrong, Governance and the Single European Market, in: The Evolution of EU Law (Paul Craig and Grainne de Búrca eds., 1999).

${ }^{170}$ Robert Boyer and JR Hollingsworth, From National Embeddedness to Spatial and Institutional Nestedness, in: CONTEMPORARY CAPITALISM: THE EMBEDDEDNESS OF INSTITUTIONS (JR Hollingsworth and Robert Boyer eds., 1997); Ronald Dore, William Lazonick and Mary O'Sullivan, Varieties of Capitalism in the Twentieth Century, 15 OXFORD REVIEW OF ECONOMIC POLICY 102 (1999); Gunther Teubner, Legal Irritants: How Unifying Law Ends Up In New Divergences, in: VARIETIES Of CAPITALISM: THE InSTITUTIONAL FOUNDATIONS Of COMPARATIVE Advantage (Peter A. Hall and David Soskice eds., 2001); Peer Zumbansen, “New Governance” in European Corporate Governance Regulation as Transnational Legal Pluralism, 15 EUROPEAN LAW JOURNAL 246 (2009)
} 
To be sure, it is a no more than trivial insight that these experiences suggest the need to pay close regard to the locally existing rules and regulatory practices - the challenge consists in determining the form and process of 'context sensitive' regulation. It is with this challenge in mind, that we are finding ourselves torn between opening our toolbox of well-worn and tested tools and concepts on the one hand and starting 'fresh', with open eyes and without prejudice on the other. ${ }^{171}$ What is remarkable in this context is the impossibility of 'breaking free' even from the semantic and symbolic stronghold of certain categories, regardless of the degree to which these have been subjected to critique, deconstruction and demystification. This is as true today ${ }^{172}$ as it was in the 1970s: ${ }^{173}$ in our search for appropriate regulatory approaches to be taken with regard to development contexts (as well as other, similarly complex regulatory spaces ${ }^{174}$ ), we strive to critically reflect on the usability of the rule of law, learned lessons with regard to democratic accountability, public deliberation or the separation of powers. Meanwhile, we realize how none of these principles can be lifted out of its context without losing some explanatory capacity, leading us back to the motivation of why we intended to draw on a particular regulatory experience in the first place. Again and again, we are confronted with the particularity of an evolutionary process in a specific space that seemingly frustrates all attempts at translation or transplantation. ${ }^{175}$ And yet, precisely because of this confrontation, we return, again and again, to a critical reflection on the categories through which we seek both to explain and to shape spaces of vulnerability and precariousness. There appears to be a crucial difference, however, between an earlier, progressive, critical exercise of such reflection and the more inchoate, interdisciplinary approach that seems to be forming today out of a combination of legal, political, sociological, economic and anthropological theory on the one hand and historical and linguistic study on the other. ${ }^{176}$ While this difference is still hard to pinpoint or to make fruitful, it becomes ever more evident that in close proximity to the continuing stand-offs between conservative and progressive struggles over development policies, the range of theory, vocabulary and categories, frameworks and imaginations is expanding. In that context, the astutely recorded accounts by Achebe of his interactions with 'third world experts', ${ }^{177}$ the extermination of interview protocols and legislative materials of law-making processes in Singapore's 'authoritarian' Rule of Law ${ }^{178}$ or the anthropological scrutiny of the World Bank's human rights programs ${ }^{179}$ — they are all and each one of them crucial elements that help draw a richer and more sophisticated picture of the development context today. In other words, we see a significant analytical expansion and deepening of our 'knowledge' basis vis-à-vis the

\footnotetext{
${ }^{171}$ See Pistor, Of Legal Transplants, supra, note

172 Kerry Rittich, The Future of Law and Development: Second Generation Reforms and the Incorporation of the Social, 26 MichigAN JOURNAL OF INTERNATIONAL LAW 199 (2004)

173 Trubek and Galanter, Scholars in Self-Estrangement, supra, note

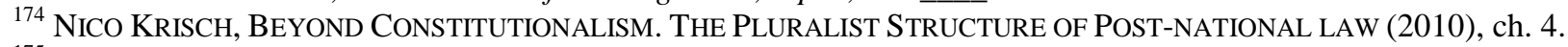

${ }^{175}$ Galit A. Sarfaty, Measuring Justice: Internal Conflict over the World Bank's Empirical Approach to Human

Rights, in: Mirrors of JustiCE: LAW AND Power IN THE POST-COLD WAR ERA (Karen Clarke and Maxine Goodale eds., 2009).

176 JOTHIE RAJAH, AUTHORITARIAN RULE OF LAW: LEGISLATION, DiSCOURSE AND LEGITIMACY IN SINGAPORE (2012), 37-52, 58-60, 288

177 ChinUA ACHEBe, THE EdUCATION OF A BRITISH-PRoteCTED CHILd (2009)

178 JothiE RAJAH, AUTHORITARIAN RULE OF LAW. LEGISLATION, DisCOURSE AND LEGITIMACY IN SiNGAPORE (2012), at 181-212

${ }^{179}$ Sally Engle Merry, Measuring the World: Indicators, Human Rights, and Global Governance in: Buchanan and Zumbansen eds., LAW IN TRANSITION: RIGHTS, DEVELOPMENT AND TRANSITIONAL JUSTICE, supra, note SARFATY, VALUES IN TRANSLATION, supra, note
} 
developmental state and the transnational 'aid and development' apparatus that is staring at it. The challenge remains in understanding and drawing the adequate lessons of such an expanding epistemic framework.

\section{En LIEU OF A CONCLUSION: THE SURPRISE THAT Is Not - All LAW IS TRANSNATIONAL}

In an effort to connect the preceding sections on the status of knowledge in hybrid legal fields such as L\&D and TJ with the opening parts of this essay on law's general relationship to globalization, let us briefly address the idea that a project such as Transnational Law can function as a "theoretical conceptualization of law after the breakdown of methodological nationalism." 180 The contention here would be that such a characterization bears considerable promise. It is in that spirit that I suggest to re-open the discussion of concepts or proposals such as TL or LP, rather than dismissing them prematurely, and perhaps under the impression that their 'deliverables' are not yet as clearly defined as one would hope. My contention is that TL and LP are mutually intertwined precisely because both struggle with the 'how' of distinguishing between legal and non-legal rules. The answer cannot be a jurisprudential one alone. Instead, what appears to follow from discussions of TL and LP is, foremost, a growing awareness of the epistemological as well as normative fragility of any attempt at boundary drawing between different norm universes in the sense evoked by Cover. ${ }^{181}$ This fragility has become a central concern in the context of debates around the 'whats' and 'hows' of global governance. In the remainder, I want to argue that proposals such as TL or LP should be seen as necessary steps in the development of theoretical approaches to a legal theory (or, legal theories ${ }^{182}$ ) of global governance [GG]. GG appears to operate in current debates as an umbrella term that is employed to capture the still open-ended and non-linear ${ }^{183}$ transformation of a nation state-based model of political rule. ${ }^{184}$ One way to address these changes with uncertain outcome has been through ambitious assessments of the nature and status of law and its tight linkages with Western notions of (different notions, stages and representations of) the state. ${ }^{185}$ One reason why TL appears to have gained temporary currency might relatively easily be found in the fact that it operates as a manageable label to depict, as suggested already by Jessup ${ }^{186}$, both overlaps of and blind spots between categorically distinguished fields (in that case public and private international law). Another reason can be identified to lie in TL's interdisciplinary nature, in that it is often times referenced from a variety of theoretical and disciplinary backgrounds precisely to capture a multitude of assertions relating to the transformation of jurisdictional (geopolitical, geographical)

\footnotetext{
${ }^{180}$ Michaels, supra, note 74 , at 18.

${ }^{181}$ Cover, Nomos and Narrative, supra, note

${ }^{182}$ I am grateful to Morag Goodwin for her insistence on that point.

${ }^{183}$ Compare Christoph Schreuer, The Waning of the Sovereign State: Towards a New Paradigm for International Law?, 4 European Journal Of InTERnAtional LAW 447 (1993), with Andreas L. Paulus, The War Against Iraq and the Future of International Law: Hegemony or Pluralism?, 25 MiCHIGAN JOURNAL OF INTERNATIONAL LAW 691 (2004).

${ }^{184}$ See the contributions to Jeffrey L. Dunoff/Joel P. Trachtman (ed.^eds.), RULING THE WORLD? 'CONSTITUTIONALISM, INTERNATIONAL LAW, AND GLOBAL GOVERNANCE (2009); see also the contributions to Thomas Hale/David Held (ed.^eds.), HANDBOOK OF TRANSNATIONAL GOVERNANCE. INSTITUTIONS AND INNOVATIONS (2011).

${ }^{185}$ See e.g. the interpretation by Dieter Grimm, The Achievement of Constitutionalism and its Prospects in a Changed World, in: ThE TwILIGHT OF CONSTITUTIONALISM? 3 (Dobner/Loughlin, eds., 2010).

${ }^{186}$ Philip C. JESSUP, TRANSNATIONAL LAW (1956).
} 
boundaries, ${ }^{187}$ shifts in norm-making competence between nationally based and spatially operating actors, ${ }^{188}$ as well as the nature of 'communities', polities, and peoples. ${ }^{189}$ A similarly positive assessment seems to be in order with regard to LP, given that legal pluralists' concern with the demarcation and politics of as well as with the tension between official and in-official bodies of norms, rules, recommendations, guidelines and standards does not - arguably - result in placing 'everything, ${ }^{190}$ on the same level, but seeks to expose, again and again, the often questionable and contestable basis on which the distinction between law and non-law is drawn in the first place. ${ }^{191}$

While the apparent frustration among many legal scholars today with the slippery nature of concepts such as TL or LP is understandable, the task of making sense of this multidisciplinary and multi-vocal engagement with globalization will eventually get easier as we all move through such stages of trial and error, exploitation, application and engagements with theory. Revisiting established legal fields, mostly thought of in their domestic, nation-state context but now reflected upon against the background of a globalization of law, we can see that the above described dilemma is in fact inherent to every area of law, long before we began inventing new names and setting novel boundaries. Examples of labor, corporate or constitutional law illustrate legal fields as epistemological and normative laboratories, through the study of which we can shed more light on the way in which law can only be understood against the background of society. And as such legal theory is inevitably caught up in the multi- and interdisciplinary efforts to adequately depict the contours and nature of today's world society.

Michael Power, Constructing the Responsible Organization: Accounting and Environmental Representation, in: Environmental Law and Ecological Responsibility: The Concept and Practice of Ecological Self-Organization 369 (Teubner/Farmer/Murphy, eds., 1994)

\footnotetext{
${ }^{187}$ See eg David Harvey, The Sociological and Geographical Imaginations, International Journal of Politics, Culture and Society 211 (2005); Saskia Sassen, Territory - Authority - Rights. From Medieval to Global Assemblages (2006).

${ }^{188}$ Colin Scott/Fabrizio Cafaggi/Linda Senden (ed.^eds.), The Challenge of Transnational Private Regulation: Conceptual and Constitutional Debates. Symposium Issue of the Journal of Law and Society, Vol. 38, No. 1, pp. 1188 (2011).

${ }^{189}$ Paul Schiff Berman, Global Legal Pluralism. A Jurisprudence of Law Beyond Borders (2012); see also Seyla Benhabib, The Rights of Others. Aliens, Residents and Citizens (2004), and Catherine Dauvergne, Making People Illegal: What Globalization Means for Migration and Law (2008).

190 But, see Michaels 32, at 18: "If everything is transnational law, nothing really is."

${ }^{191}$ See eg, Marc Galanter, In the Winter of our Discontent: Law, Anti-Law, and Social Science, Annual Review of Law \& Social Sciences 1 (2006).
} 